\title{
Synthesis, Structure and Nickel Carbonyl Complexes of Dialkylterphenyl Phosphines
}

\author{
Mario Marín, ${ }^{[b]}$ Juan J. Moreno, ${ }^{[a]}$ Carlos Navarro-Gilabert, ${ }^{[a]}$ Eleuterio Álvarez, ${ }^{[a]}$ Celia Maya, ${ }^{[a]}$ Riccardo \\ Peloso, ${ }^{[a]}$ M. Carmen Nicasio, ${ }^{*[b]}$ Ernesto Carmona*[a]
}

\section{Dedicated to Professor William D. Jones on the occasion of his 65th birthday}

\begin{abstract}
We describe the experimental and computational characterization of a series of dialkylterphenyl phosphines, $\mathrm{PR}_{2} \mathrm{Ar}^{\prime}$ (Figure 2). Molecules of composition $\mathrm{PR}_{2} \mathrm{Ar}^{\mathrm{Dtbp}}{ }_{2}$, for $\mathrm{R}=\mathrm{Me}$, Et, 'Pr, $c-\mathrm{C}_{5} \mathrm{H}_{9}$ and $c-\mathrm{C}_{6} \mathrm{H}_{11}$, are accompanied by five $\mathrm{PR}_{2} \mathrm{Ar}^{\prime}$ phosphines containing the bulky alkyl groups ${ }^{i} \mathrm{Pr}, c-\mathrm{C}_{5} \mathrm{H}_{9}$ or $c^{-}$ $\mathrm{C}_{6} \mathrm{H}_{11}$, in combination with $\mathrm{Ar}^{\prime}=\mathrm{Ar}^{\mathrm{Xyl}_{2}}$, $\mathrm{Ar}^{\mathrm{Xyl}_{2}}$, or $\mathrm{Ar}^{\mathrm{Ph}_{2}}$ (L1-L10). Steric and electronic parameters have been determined computationally and from IR and X-ray data obtained for the phosphines and for some derivatives, including tricarbonyl and dicarbonyl nickel complexes, $\mathrm{Ni}(\mathrm{CO})_{3}\left(\mathrm{PR}_{2} \mathrm{Ar}^{\prime}\right)$ and $\mathrm{Ni}(\mathrm{CO})_{2}\left(\mathrm{PR}_{2} \mathrm{Ar}{ }^{\prime}\right)$. In the solid state, molecules of $\mathrm{PR}_{2} \mathrm{Ar}$ ' adopt one of the three possible structures represented in Figure 3, formally related by rotation around the $\mathrm{C}_{i p s o}-\mathrm{P}$ bond. Information on their relative energies and on the influence of the free phosphine structure on its coordination chemistry towards $\mathrm{Ni}(\mathrm{CO})_{n}(\mathrm{n}=2,3)$ fragments has been gained by experimental and computational methods.
\end{abstract}

\section{Introduction}

Tertiary phosphines, $\mathrm{PR}_{3}$, and related molecules containing a three-coordinate phosphorus atom, $\mathrm{PX}_{3}\left(\mathrm{X}=\mathrm{OR}, \mathrm{NR}_{2}\right.$ and others), form an invaluable family of ligands, with an influence in organometallic chemistry and homogeneous catalysis that cannot be overstated..$^{1-3}$ By and large, during the second half of the past century, studies on transition metal complexes focused on alkyl and aryl phosphines such as $\mathrm{PMe}_{3}, \mathrm{P}^{\mathrm{P} P r_{3}}, \mathrm{P}\left(c-\mathrm{C}_{6} \mathrm{H}_{11}\right)_{3}, \mathrm{PPh}_{3}$ and others. Notwithstanding the versatility of these ligands, relatively little progress was made on the synthesis of monodentate phosphines until fairly recently. ${ }^{4}$ Some twenty years ago, Buchwald and coworkers demonstrated that when bound to palladium, dialkylbiaryl phosphines were able to catalyse with high proficiency $\mathrm{C}-\mathrm{C}$ and $\mathrm{C}-\mathrm{N}$ coupling reactions of aryl halides, including unactivated aryl chlorides. ${ }^{5}$ Lately, Buchwald's

[a] J. J. Moreno, C. Navarro-Gilabert, Dr. Eleuterio Álvarez, Dr. Celia Maya, Dr. R. Peloso, Prof. Dr. E. Carmona

Instituto de Investigaciones Químicas (IIQ), Departamento de Química Inorgánica and Centro de Innovación en Química Avanzada (ORFEO-CINQA), Consejo Superior de Investigaciones Científicas (CSIC) and Universidad de Sevilla

Avda. Américo Vespucio 49, 41092 Sevilla, Spain

E-mail: guzman@us.es

[b] M. Marín, Prof. Dr. M. C. Nicasio

Departamento de Química Inorgánica, Universidad de Sevilla Aptdo 1203, 41071 Sevilla (Spain)

E-mail:mnicasio@us.es

Supporting information for this article is given via a link at the end of the document. phosphines, ${ }^{6}$ along with other bulky phosphines, ${ }^{7-9}$ have become indispensable ligands in organometallic chemistry and catalysis, and within the recent past many tertiary phosphines of assorted electronic and steric characteristics have been made available. ${ }^{10-}$ 15

As of late, remarkable success in unveiling subtle phosphine ligand effects has been witnessed in nickel, palladium and gold catalysis. ${ }^{16}$ Besides, for tri(1-adamantyl)phosphine, a molecule for which steric and electronic properties beyond conventional limits were disclosed, unique catalytic features, seemingly influenced by van der Waals dispersion forces, ${ }^{17}$ were uncovered. ${ }^{12 a}$ Furthermore, widely used parameters such as Tolman's cone angle $\theta^{18}$ and the buried volume $\% \mathrm{~V}_{\text {bur }}{ }^{19}$ may be envisaged as accounting, respectively, for remote and proximal steric effects, the former potentially giving rise to significant dispersion forces. ${ }^{16 a}$

The impact of dialkylbiaryl phosphines in organotransition metal chemistry and catalysis prompted us to explore the $m$ terphenyl analogues, $\mathrm{PR}_{2} \mathrm{Ar}$, for $\mathrm{Ar}^{\prime}=$ terphenyl radical. The conspicuous features of sterically demanding terphenyl fragments, either as bulky organometallic aryl ligands ${ }^{20}$ or as substituents of various types of Lewis bases ${ }^{21,22}$ have been investigated. At the outset of our work, however, just a few terphenyl phosphine ligands, and a consequently small number of their complexes with late transition metals, had been described. ${ }^{23-25}$ Our first reports centred Rh, Ir, Pt and Au of $\mathrm{PMe}_{2} A r^{\prime}$ phosphines $\left(\mathrm{Ar}^{\prime}=\mathrm{C}_{6} \mathrm{H}_{3}-2,6\right.$ $\left(\mathrm{C}_{6} \mathrm{H}_{3}-2,6-\mathrm{R}_{2}\right)_{2}$ for $\mathrm{R}=\mathrm{Me}$ and $\mathrm{Pr}$, in shorthand notation $\mathrm{PMe}_{2} \mathrm{Ar}^{\mathrm{Xyl}} \mathrm{L}_{2}$ and $\mathrm{PMe}_{2} \mathrm{Ar}^{\mathrm{Dipp}}{ }_{2}$, respectively), and evinced their aptitude to stabilize low-coordinate structures, as well as their potential to adopt different coordination modes (Figure 1), where $\mathrm{P}$-bonding is complemented by relatively weak $\mathrm{M} \cdots \mathrm{C}_{\text {arene }}$ interactions with a flanking aryl ring of the terphenyl substituent. ${ }^{23-}$
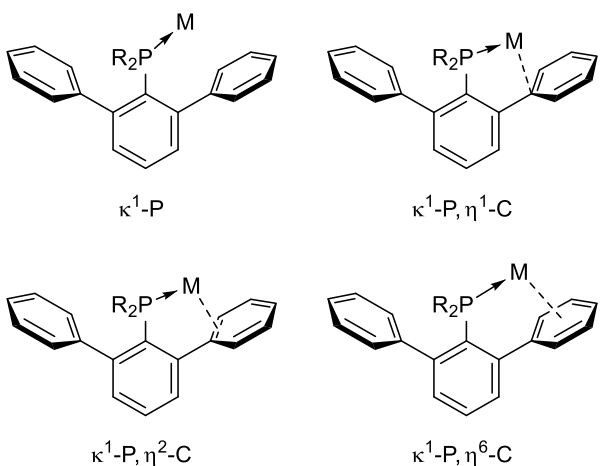

Figure 1. Different coordination modes found for terphenyl phosphines. ${ }^{23-28}$

The objective of the present work was the description of a series of $\mathrm{PR}_{2} \mathrm{Ar}$ ' molecules selected in accordance with the 
<smiles>COc1c(-c2cc(Br)cc(Br)c2)cccc1-c1cc(Br)c(Br)cc1Br</smiles>

$\mathrm{PMe}_{2} \mathrm{Ar}^{\mathrm{Dtbp} 2}$, ㄴ1

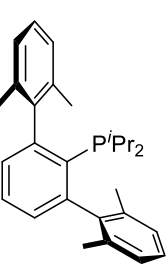

$\mathrm{P}^{\mathrm{i}} \mathrm{Pr}_{2} \mathrm{Ar}^{\mathrm{Xyl}}, \underline{\underline{\mathbf{L}}}$

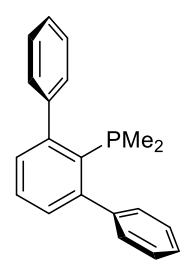

$\mathrm{PMe}_{2} \mathrm{Ar}^{\mathrm{Ph}_{2}}, \underline{\mathrm{L} 11}$

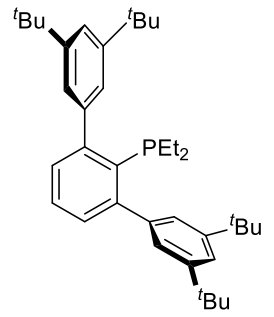

$\mathrm{PEt}_{2} \mathrm{Ar}^{\mathrm{Dtbp}_{2}}$, L2

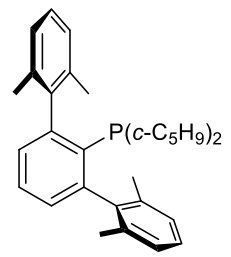

$\mathrm{P}\left(\mathrm{c}-\mathrm{C}_{5} \mathrm{H}_{9}\right)_{2} \mathrm{Ar}^{\mathrm{Xyl}}, \underline{\mathbf{L} 7}$

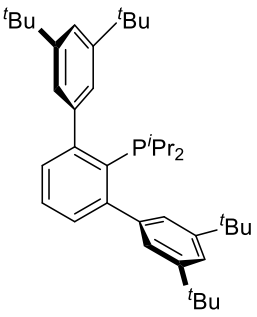

$\mathrm{P}^{\mathrm{i}} \mathrm{Pr}_{2} \mathrm{Ar}^{\mathrm{Dtbp}}$, $\underline{\mathbf{L 3}}$

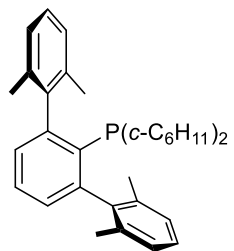

$\mathrm{P}\left(\mathrm{c}-\mathrm{C}_{6} \mathrm{H}_{11}\right)_{2} \mathrm{Ar}^{\mathrm{Xyl}}, \underline{\mathbf{L} 8}$
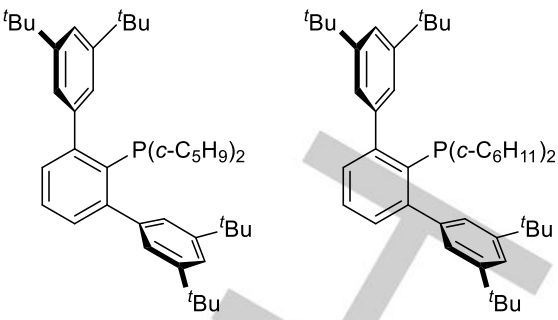

$\mathrm{P}\left(\mathrm{c}-\mathrm{C}_{5} \mathrm{H}_{9}\right)_{2} \mathrm{Ar}^{\mathrm{Dtbp}}, \underline{\mathrm{L} 4}$
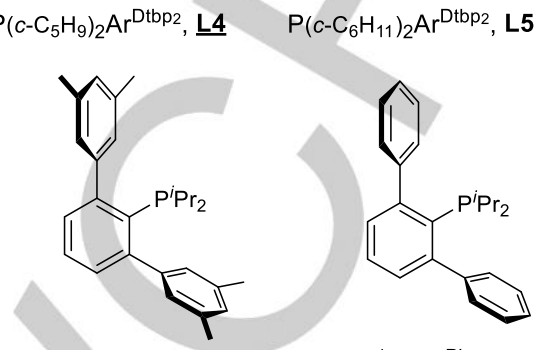

$\mathrm{P}^{\mathrm{i}} \mathrm{Pr}_{2} \mathrm{Ar}^{\mathrm{Xyl}}{ }^{\prime 2}$, L9

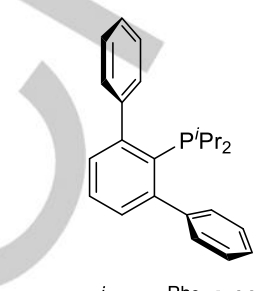

$\mathrm{P}^{\mathrm{i}} \mathrm{Pr}_{2} \mathrm{Ar}^{\mathrm{Ph}}{ }^{2}, \mathrm{~L} 10$

Figure 2. Structural formulae, abbreviated names and numbering scheme for the terphenyl phosphines described in this work (upper part) and others already in the literature (bottom row). Crystallographic data for phosphines with underlined numbers available. ${ }^{\text {[a] }}$ See reference 24a.

following criteria. Firstly, besides some $\mathrm{PMe}_{2}$-containing phosphines, ${ }^{28,29}$ we set out to prepare $\mathrm{PR}_{2} \mathrm{Ar}^{\prime}$ phosphines of the branched and cyclic alkyl groups ${ }^{i} \mathrm{Pr}$ and $c-\mathrm{C}_{6} \mathrm{H}_{11}$, respectively, which are phosphine substituents extensively employed in organometallic chemistry and catalysis. The new terphenyl phosphines find applications in efficient Pd-catalyzed amination reactions and $\mathrm{Cu}$-promoted cycloaddition of azides and alkynes. These and other catalytic processes will be described separately. We also considered of interest the c-pentyl phosphine analogues, ${ }^{30-35}$ despite known drawbacks for $\mathrm{P}\left(c-\mathrm{C}_{5} \mathrm{H}_{9}\right)_{3}$ as, for instance, its facile oxidation and the higher reactivity of $c-\mathrm{C}_{5} \mathrm{H}_{9}$ rings relative to $c-\mathrm{C}_{6} \mathrm{H}_{11}$ ones, due mainly to steric strains. ${ }^{34}$ For the second group of phosphines, we chose a terphenyl moiety containing two 3,5-bis(t-butyl)phenyl substituents, $3,5-\mathrm{C}_{6} \mathrm{H}_{3}$ $\left(\mathrm{CMe}_{3}\right)_{2}$, at the 2- and 6-positions of the central aryl ring (in short $\left.A r^{\mathrm{Dtbp} 2}\right)$. As presented in Figure 2, a total of five $\mathrm{PR}_{2} \mathrm{Ar}^{\mathrm{Dtbp}}{ }_{2}$ ligands have been prepared for $\mathrm{R}=\mathrm{Me}$, Et, ${ }^{\mathrm{P}} \mathrm{Pr}, c-\mathrm{C}_{5} \mathrm{H}_{9}$ and $c-\mathrm{C}_{6} \mathrm{H}_{11}$, (L1L5). Attempts to prepare their tert-butyl analogues, $\mathrm{P}^{t} \mathrm{Bu}_{2} \mathrm{Ar}$ ', proved unsuccessful.

Here, we focus attention on ligand synthesis and structural characterization by $\mathrm{X}$-ray diffraction methods. We show that all dialkylterphenyl phosphines that have been authenticated by $X$ ray crystallography, exhibit a solid-state structure that corresponds to one of the three conformations depicted in Figure 3 , for which different coordination properties towards unsaturated metal fragments, $M L_{n}$, can be foreseen. Besides, we consider closely $\mathrm{Ni}(0)-\mathrm{CO}-\mathrm{PR}_{2} \mathrm{Ar}^{\prime}$ complexes, not only tricarbonylphosphine species, $\mathrm{Ni}(\mathrm{CO})_{3}\left(\mathrm{PR}_{2} \mathrm{Ar} \mathbf{r}^{\prime}\right)$, 1.PR $\mathbf{P} \mathbf{A r}$ ', similar to those employed by Tolman to ascertain phosphine electronic properties, ${ }^{35}$ but also some $\mathrm{Ni}(\mathrm{CO})_{2}\left(\mathrm{PR}_{2} \mathrm{Ar}{ }^{\prime}\right)$ derivatives, 2. $\mathbf{P R}_{2} \mathbf{A r}$ ', for which an uncommon oblique trigonal pyramidal geometry, with a relatively weak $\mathrm{Ni}-\eta^{2}-\mathrm{C}_{\text {arene }}$ interaction has been unveiled. Although many $\mathrm{Ni}(0)$ tricoordinate complexes are familiar, analogous phosphine dicarbonyl $\mathrm{Ni}(0)$ compounds are unknown. Furthermore, we were surprised to learn that nearly fifty years after the generation by Tolman of $\mathrm{Ni}(\mathrm{CO})_{3}\left(\mathrm{PR}_{3}\right)$ complexes in $\mathrm{CH}_{2} \mathrm{Cl}_{2}$ solutions, ${ }^{35}$ there is an astonishing dearth of crystallographic information on compounds of this type. ${ }^{36}$

\section{Results and Discussion}

\section{Synthesis and spectroscopic characterization of $\mathrm{PR}_{2} \mathrm{Ar}$ ' ligands}

Our recent synthesis of terphenyl phosphines, $\mathrm{PR}_{2} \mathrm{Ar}^{\prime},{ }^{28}$ followed a slightly modified earlier procedure ${ }^{23 a}$ and consisted in the stepwise reaction of a terphenyl Grignard reagent, $M g\left(A r^{\prime}\right) X$, with $\mathrm{PCl}_{3}$, followed by alkylation using, once more, the appropriate magnesium agent, $\mathrm{Mg}(\mathrm{R}) \mathrm{Br}$, as shown in Scheme 1a. Whereas this method yields satisfactory results for linear hydrocarbyl $R$ groups and it was thus applicable to the synthesis of the new phosphines L1 and L2, attempts to extend it to the branched or cyclic $i$-propyl, $c$-pentyl and $c$-hexyl phosphines led either to unreacted starting materials or to complex mixtures of products that could not be characterized (Scheme 1b). Emulating the synthesis of biaryl phophines, ${ }^{37}$ the alkylation of $\mathrm{PX}_{2} \mathrm{Ar}^{\prime}$ was 
effected in the presence of $\mathrm{CuCl}$. After careful monitoring of reaction conditions (temperature, concentration of reagents and copper salt), best results were obtained performing the reaction at room temperature and using $\mathrm{PX}_{2} \mathrm{Ar}$ ': $\mathrm{Mg}(\mathrm{R}) \mathrm{Br}$ molar ratios of $c a$. $1: 4$, in the presence of overstoichiometric quantities of $\mathrm{CuCl}$ (approximately 1.5 equiv. relative to $\mathrm{PX}_{2} \mathrm{Ar}^{\prime}$ ). The formation of the target phosphines was always accompanied by small amounts of $\mathrm{Cu}(\mathrm{X})\left(\mathrm{PR}_{2} \mathrm{Ar}^{\prime}\right)$ complexes. Work-up of reaction mixtures was complicated by the generation of metallic copper and of sticky, insoluble materials that easily clogged filtration apparatus. ${ }^{37 \mathrm{~b}}$ The synthesis of the new phosphines is summarized in Scheme 2, particular details regarding their purification are presented in the Experimental Section and the Supporting Information. As stated earlier, all attemps to prepare $\mathrm{P}^{t} \mathrm{~B} \mathrm{u}_{2} \mathrm{Ar}$ ' phosphines were fruitless.
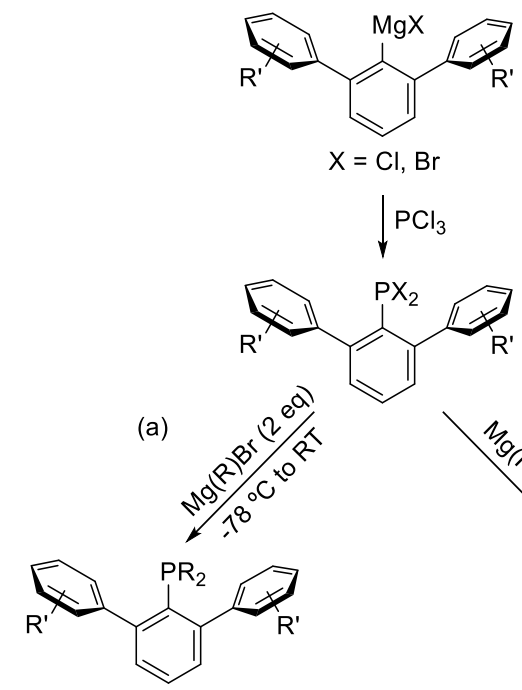

$\downarrow \mathrm{PCl}_{3}$<smiles>[R]c1cccc(-c2cccc(-c3ccccc3)c2[R12])c1</smiles>

$\mathrm{R}=$ linear hydrocarbyl group

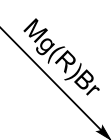

(b) in $50-60 \%$ yields, hence comparable to those given originally for dialkylbiaryl analogues ${ }^{37}$ and for the recently prepared $\mathrm{PMe}_{2} \mathrm{Ar}^{\prime}$ (Methyl-JohnPhos; ca. 52\% three-step overall yield). ${ }^{29 b}$ With the exception of $\mathrm{PEt}_{2} \mathrm{Ar}^{\mathrm{Xyl}_{2}}$, L16, reported to form in unexpected low yields (about $40 \%$ ), ${ }^{28}$ it can be noticed that sterically demanding $\mathrm{R}$ groups provoke a significant decrease in isolated yields, which remain in the $35-60 \%$ range for ${ }^{~} \mathrm{Pr}, c-\mathrm{C}_{5} \mathrm{H}_{9}$ and $c-\mathrm{C}_{6} \mathrm{H}_{11}$, in contrast with the $70-80 \%$ values of the $\mathrm{PMe}_{2} \mathrm{Ar}^{\prime}$ analogues. This may explain failure to isolate $\mathrm{P}^{t} \mathrm{Bu}_{2} \mathrm{Ar}^{\prime}$ phosphines. It appears plausible that steric hindrance triggers side reactions involving, among others, formal hydride transfer from $\mathrm{Mg}(\mathrm{R}) \mathrm{Br}$ to $\mathrm{PX}(\mathrm{R}) \mathrm{Ar}$ intermediates, thereby giving rise to alkene and secondary phosphine $\mathrm{P}(\mathrm{H}) \mathrm{R}\left(\mathrm{Ar}^{\prime}\right)$ products. ${ }^{38}$ In support of this hypothesis, ${ }^{31} \mathrm{P}$ NMR resonances around $-40 \mathrm{ppm}$, that could be due to $\mathrm{P}(\mathrm{H}) \mathrm{R}\left(\mathrm{Ar} \mathrm{r}^{\prime}\right)$ molecules, ${ }^{39}$ were frequently detected in the reaction crudes. Furthermore, reactions aimed at the synthesis of $\mathrm{PR}_{2} \mathrm{Ar}^{\mathrm{Dipp}}{ }_{2}$, for $\mathrm{R}=\operatorname{Pr}, c-\mathrm{C}_{5} \mathrm{H}_{9}$ and $c-\mathrm{C}_{6} \mathrm{H}_{11}$, did not afford the desired products, and for $\mathrm{R}=\mathrm{C}-\mathrm{C}_{5} \mathrm{H}_{9}$ the secondary phosphine

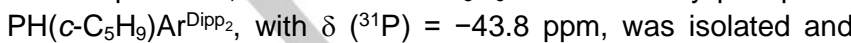
characterized by X-ray crystallography (see the SI, Figure S9). The similar phosphine $\mathrm{PH}(\mathrm{Pr}) \mathrm{Ar}^{\mathrm{Xy} \mathrm{I}_{2}}$, with $\delta\left({ }^{31} \mathrm{P}\right)=-37.7 \mathrm{ppm}$, was also isolated and characterized (see the $\mathrm{SI}$ ).

Table 1. Yields (based on $\mathrm{P}),{ }^{31} \mathrm{P}\left\{{ }^{1} \mathrm{H}\right\}$ NMR chemical shifts and $\Sigma \mathrm{C}-\mathrm{P}-\mathrm{C}$ angles for the ligands listed in Figure 2

\begin{tabular}{|c|c|c|c|}
\hline Ligand & Yield (\%) & $\begin{array}{c}{ }^{31} \mathrm{P}\left\{{ }^{1} \mathrm{H}\right\} \\
\mathrm{NMR}(\mathrm{ppm})\end{array}$ & $\Sigma \mathrm{C}-\mathrm{P}-\mathrm{C}(\stackrel{\circ}{)})$ \\
\hline L1, $\mathrm{PMe}_{2} \mathrm{Ar}^{\mathrm{Dtbp}} 2$ & 71 & -36.6 & 298.53 \\
\hline L2, $\mathrm{PEt}_{2} \mathrm{Ar}^{\mathrm{Dtbp}_{2}}$ & 65 & -12.8 & \\
\hline L3, $\mathrm{P}^{\mathrm{i}} \mathrm{Pr}_{2} \mathrm{Ar}^{\mathrm{Dtbp}}{ }_{2}$ & 49 & 12.6 & 310,72 \\
\hline L4, $\mathrm{P}\left(c-\mathrm{C}_{5} \mathrm{H}_{9}\right)_{2} \mathrm{Ar}^{\mathrm{Dtbp}_{2}}$ & 37 & 0.9 & 309,44 \\
\hline L5, $\mathrm{P}\left(c-\mathrm{C}_{6} \mathrm{H}_{11}\right)_{2} \mathrm{Ar}^{\mathrm{Dtbp}} 2$ & 51 & 1.6 & \\
\hline L6, $\mathrm{P}^{\mathrm{P}} \mathrm{Pr}_{2} \mathrm{Ar}^{\mathrm{Xy} \mathrm{l}_{2}}$ & 57 & 16.2 & 315,84 \\
\hline L7, $\mathrm{P}\left(c-\mathrm{C}_{5} \mathrm{H}_{9}\right)_{2} \mathrm{Ar}^{\mathrm{Xyl}_{2}}$ & 57 & 4.6 & 313,84 \\
\hline L8, $\mathrm{P}\left(c-\mathrm{C}_{6} \mathrm{H}_{11}\right)_{2} \mathrm{Ar}^{\mathrm{Xyl_{2 }}}$ & 56 & 10.1 & 316,59 \\
\hline L9, $\mathrm{P}^{\mathrm{P}} \mathrm{Pr}_{2} \mathrm{Ar}^{\mathrm{Xy}{ }^{\prime}}{ }_{2}$ & 53 & 15.3 & \\
\hline 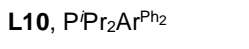 & 58 & 16.3 & \\
\hline L11, $\mathrm{PMe}_{2} \mathrm{Ar}^{\mathrm{Ph}_{2}[\mathrm{a}]}$ & 80 & -35.8 & 298,63 \\
\hline L12, $\mathrm{PMe}_{2} \mathrm{Ar}^{\mathrm{Xyl_{2 }}[\mathrm{b}]}$ & 60 & -40.4 & 309,76 \\
\hline L13, $\mathrm{PMe}_{2} \mathrm{Ar}^{\mathrm{Mes}}[\mathrm{c}]$ & 65 & -36.9 & 309,02 \\
\hline L14, $\mathrm{PMe}_{2} \mathrm{Ar}^{\mathrm{Dipp}} 2$ [d] & 54 & -41.3 & 308,45 \\
\hline L15, $\mathrm{PMe}_{2} \mathrm{Ar}^{T r i p p_{2}}$ [a] & 54 & -40.7 & \\
\hline L16, $\mathrm{PEt}_{2} \mathrm{Ar}^{\mathrm{Xyl}_{2} \text { [a] }}$ & 40 & -8.0 & \\
\hline
\end{tabular}

[a] See ref. 28. [b] See ref. 26a. [c] See ref. 23a. [d] See ref. 26b.

The new terphenyl phosphines were obtained as analytically pure white solids that could be stored under air for extended periods of time. This is in agreement with the behaviour unveiled previously for dialkylbiaryl phosphines. ${ }^{29,40 a}$ Some of the $\mathrm{PR}_{2} \mathrm{Ar}^{\prime}$ phosphines exhibit solution dynamic behaviour, as discussed later for $\mathrm{P}^{\mathrm{P} P} \mathrm{Ar}_{2} \mathrm{Ar}^{\mathrm{Dtbp}} \mathrm{C}_{2}$, L3. In general, however, the room temperature ${ }^{1} \mathrm{H}$ and ${ }^{13} \mathrm{C}\left\{{ }^{1} \mathrm{H}\right\}$ NMR spectra recorded for L1-L10 are simple and indicative of a high degree of apparent symmetry introduced by rotation around the $\mathrm{P}-\mathrm{C}_{i p s o}$ bond. ${ }^{31} \mathrm{P}\left\{{ }^{1} \mathrm{H}\right\}$ chemical shifts span a range of over 50 ppm (Table 1), from -36.6 (L1) to $16.3 \mathrm{ppm}$ (L10). As expected, the major influence in the $\delta$ value comes from the R groups. ${ }^{10,39}$ Given that, as already pointed out, the syntheses of bulky phosphines often give rise to kinetically
Table 1 collects relevant information on the new phosphines L1-L10. Corresponding data reported originally for L11-L16 are also included. Before discussing pertinent characterization data, trends in isolated yields deserve some brief comments. All phosphines but L16 and $\mathbf{L} \mathbf{9}$ can be produced on gram-scale runs 
competitive, undesirable side reactions, predicting the ${ }^{31} \mathrm{P} N M R$ chemical shifts of target molecules can be helpful. With the aid of the ${ }^{31} \mathrm{P}$ NMR contributions compiled for the R groups of L1-L10, ${ }^{10}$ the $\delta$ values listed in Table 1 lead to group contributions for $\mathrm{Ar}^{\mathrm{Xyl}_{2}}$ and $\mathrm{Ar}^{\mathrm{Dtbp}_{2}}$ of approximately +4 and $+1 \mathrm{ppm}$, respectively. A comparable value of $+2 \mathrm{ppm}$ can be estimated for $\mathrm{Ar}^{\mathrm{Dipp}} \mathrm{p}_{2}$, yet the latter is based on only two $\mathrm{PR}_{2} \mathrm{Ar}^{\mathrm{Dipp} 2}$ phosphines (Table 1). It should be remarked that for tertiary phosphines, deviations between estimated and experimental values are usually $\leq 3 \mathrm{ppm}$, exceeding rarely 6 ppm. ${ }^{10}$

\section{Solution, X-ray and Gas-Phase Molecular Structure of Dialkylterphenyl Phosphines, $\mathrm{PR}_{2} \mathrm{Ar}$ '}

The solid-state structures of the molecules of the newly reported terphenyl phosphines L1, L3, L4 and L6-L8 were determined by X-ray crystallography. To have on hand a sufficiently large number of structures, the molecular geometries of $\mathrm{PMe}_{2} \mathrm{Ar}^{\mathrm{Ph}_{2}}$ (L11), $\mathrm{PMe}_{2} \mathrm{Ar}^{\mathrm{Xyl}}{ }_{2}$ (L12) and $\mathrm{PMe}_{2} \mathrm{Ar}^{\mathrm{Dipp}_{2}}$ (L14) were also ascertained. ${ }^{28}$ Adding these $X$-ray data to other already reported, ${ }^{24 a, 28}$ a structural database of more than a dozen X-ray structures becomes currently available, allowing to discriminate among three distinct phosphine conformations which formally interconvert by rotation around the $\mathrm{C}_{i p s o}-\mathrm{P}$ bond (Figure 3 ). Supplementary to X-ray analysis, solution and computational studies on selected phosphines were developed.

The three solid-state structural types are represented schematically in Figure 3 with A, B and C labels. Notice, however, that in Figure 3: (i) The R' substitution pattern at the side rings is 3,5 in $\mathbf{A}$ but 2,6 in $\mathbf{B}$. (ii) $\mathrm{PMe}_{2} \mathrm{Ar}^{\prime}$ phosphines exhibit structure of type $\mathbf{A}$ or $\mathbf{B}$, while $\mathbf{C}$ is characteristic of the bulkier $\mathrm{PR}_{2} \mathrm{Ar}^{\prime}$ phosphines presented in Figure $2\left(\mathrm{R}={ }^{i} \mathrm{Pr}, c-\mathrm{C}_{5} \mathrm{H}_{9}\right.$ or $\left.c-\mathrm{C}_{6} \mathrm{H}_{11}\right)$. (iii) To mitigate steric hindrance between the $\mathrm{P}$-bound alkyl groups and the neighbouring flanking ring, the $\mathrm{PR}_{2}$ moiety in structures $\mathrm{B}$ and $\mathbf{C}$ bends away from the ring in close proximity, such that one of the P-Cipso- $\mathrm{C}_{\text {ortho }}$ angles widens $\left(>120^{\circ}\right)$ at the expense of the other $\left(<120^{\circ}\right)$.

On the basis of the experimental and computational results discussed in this work, we propose that a certain phosphine $\mathrm{PR}_{2} \mathrm{Ar}^{\prime}$ adopts in the solid state one of the three A, B or C structures, depending on steric repulsions among the phosphorus substituents and electron-electron repulsion between the phosphorus atom lone pair and the $\pi$-system of the adjacent ring. On these grounds, structure $\mathbf{A}$ is the preferred geometry for the least sterically demanding phosphines studied, namely $\mathrm{PMe}_{2} \mathrm{Ar}^{\mathrm{Dtbp}}{ }_{2}$ (L1) and $\mathrm{PMe}_{2} \mathrm{Ar}^{\mathrm{Ph}_{2}}$ (L11), the two featuring P-Me bonds and no ring substitution at positions 2 and 6 . Besides L1 and L11, $\mathbf{A}$ is also the structural type found for $\mathrm{P}(\mathrm{H})_{2} \mathrm{Ar}^{\mathrm{Mes}_{2}}$ and $\mathrm{PMe}_{2} \mathrm{Ar}^{\mathrm{Xyl}}{ }_{2}\left(\mathrm{Mes}=2,4,6-\mathrm{C}_{6} \mathrm{H}_{2} \mathrm{Me}_{3} ; \mathrm{Xyl}{ }^{\prime}=3,5-\mathrm{C}_{6} \mathrm{H}_{3} \mathrm{Me}_{2}\right.$ ), reported by Wehmschulte and coworkers. ${ }^{24 a}$

Concerning $\mathrm{PMe}_{2} \mathrm{Ar}^{\prime}$ phosphines bearing 2,6-disubstituted flanking rings, the enlarged steric impediments brought in by these substituents results in an observable structural change from conformation $\mathbf{A}$ to $\mathbf{B}$. Combination of a ca. $50^{\circ}$ rotation of the $\mathrm{PMe}_{2}$ half around the $\mathrm{P}-\mathrm{C}_{\text {ipso }}$ bond to make one of the $\mathrm{P}-\mathrm{Me}$ bonds almost coplanar with the Ar' central ring, and opening of the P$\mathrm{C}_{\text {ipso }}-\mathrm{C}_{\text {ortho }}$ bond angle of the $\mathrm{PMe}_{2}$ unit and the closer side ring, partially relieves steric tension making conformation $\mathbf{B}$ somewhat more favourable than A. Experimentally, this is the molecular geometry ascertained for $\mathrm{PMe}_{2} \mathrm{Ar}^{\mathrm{Xyl}_{2}}$ (L12) and $\mathrm{PMe}_{2} \mathrm{ArDipp}_{2}$ (L14), as well as for the previously reported ${ }^{24 a, 28} \mathrm{PMe}_{2} \mathrm{Ar}^{\mathrm{Mes}_{2}}$ (L13),
$\mathrm{P}(\mathrm{C} \equiv \mathrm{CH})_{2} \mathrm{Ar}^{\mathrm{Mes}_{2}}, \mathrm{P}\left(\mathrm{CH}_{2} \mathrm{CH}=\mathrm{CH}_{2}\right)_{2} \mathrm{Ar} \mathrm{Dipp}_{2}$ and the Buchwald-type biaryl phosphine Methyl-JohnPhos. ${ }^{29 a}$

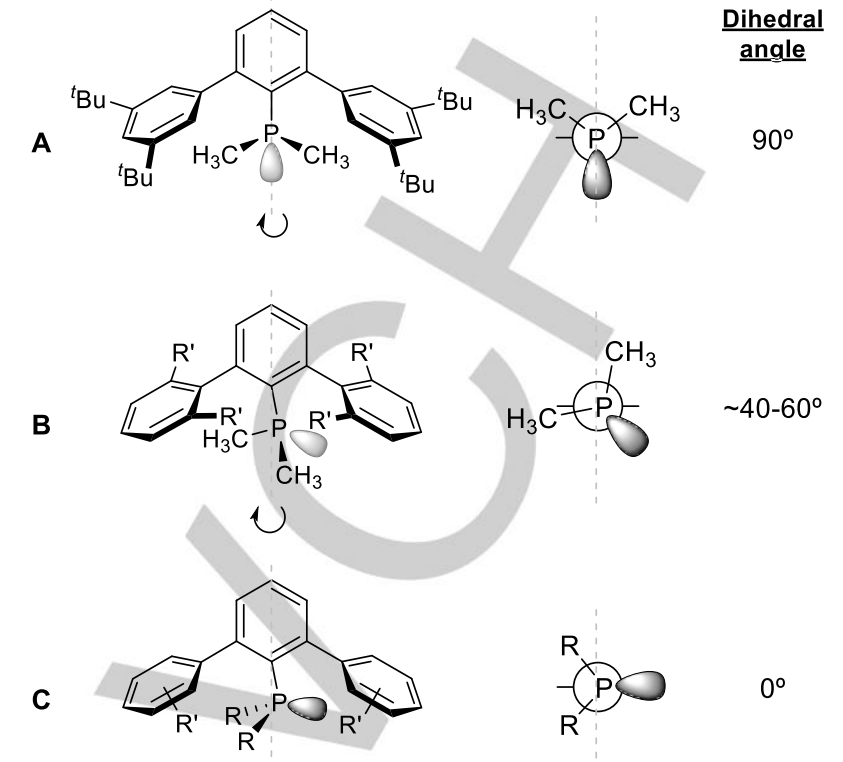

Figure 3. Different conformations adopted by dialkylterphenyl phosphines in the solid state.

The third type of structure found in the solid-state for the $\mathrm{PR}_{2} \mathrm{Ar}^{\prime}$ investigated becomes the preferred one for the bulky, branched or cyclic alkyl groups $\mathrm{Pr}, c-\mathrm{C}_{5} \mathrm{H}_{9}$ and $c-\mathrm{C}_{6} \mathrm{H}_{11}$ (L3, L4, L6-L8 in Figure 2). Now, steric hindrance among the $\mathrm{R}$ groups and the substituents at the flanking aryl rings forces the bulky $P$. bonded alkyl units to place themselves above and below the plane of the central aryl ring, i.e. frontwards and backwards in the perspective shown for conformation $\mathbf{C}$ in Figure 3. Likewise, and similar to structure $\mathbf{B}$, to relieve steric tension between the $R$ groups and the proximal ring, the $\mathrm{PR}_{2}$ moiety bends away from the ring, enlarging the corresponding $\mathrm{P}-\mathrm{C}_{i p s o}-\mathrm{C}_{\text {ortho }}$ bond angle (see below for details). Interestingly, along with the bulky $\mathrm{PR}_{2} \mathrm{Ar}^{\prime}$ phosphines studied in this work, all the sterically demanding dialkylbiaryl phosphines analysed by the group of Buchwald, ${ }^{40 a}$ or by others, ${ }^{40 \mathrm{~b}, \mathrm{c}}$ feature also a structure of type $\mathbf{C}$.

To gain insights into the solution behaviour of terphenyl phosphines, variable temperature NMR and complementary computational studies were additionally carried out. A comparative analysis of $\mathrm{PMe}_{2} \mathrm{Ar}^{\mathrm{Dtbp}_{2}}$ (L1, structure A) and $\mathrm{PiPr}_{2} \mathrm{Ar}^{\mathrm{Dtbp}}{ }_{2}$ (L3, structure $\mathbf{C}$ ), appears appropriate. Computational calculations revealed that for $\mathbf{L} \mathbf{1}$, rotation around the P-Cipso bond is a very facile process, with transition states between conformations of the order of $3-3.5 \mathrm{kcal} \cdot \mathrm{mol}^{-1}$ relative to the ground state structure (Figure S1). This is in accordance with solution NMR data down to $-80^{\circ} \mathrm{C}$, where both flanking rings remain equivalent (Figure S3). In contrast, the ${ }^{1} \mathrm{H}$-NMR spectrum of $L 3$ reveals inequivalence of the two rings at $-80^{\circ} \mathrm{C}$, as denoted, for instance, by the observation of two signals for the $t$-Bu groups with $\delta 1.29$ and $1.28 \mathrm{ppm}$, or by the appearance of two distinct signals (7.17 and $7.04 \mathrm{ppm}$ ) for the ortho $\mathrm{H}$ atoms of the Dtbp rings (Figure S4). Upon warming, exchange of the flanking rings becomes faster, averaging the exchanging sites. Thus, at $-50^{\circ} \mathrm{C}$ the two $t$-Bu resonances merge and originate a broad signal centred at $1.33 \mathrm{ppm}$. From this and other data of the interchanging $\mathrm{H}$-positions, an energy barrier $\Delta \mathrm{G}^{\ddagger} \approx 11.7 \mathrm{kcal} \cdot \mathrm{mol}^{-1} \mathrm{can}$ be 
estimated, using Eyring equation and the value of the rate constant determined at the coalescence temperature $\left(-50^{\circ} \mathrm{C}\right)$. In reasonable agreement with these experimental results, the computational analysis of terphenyl rotation around the $\mathrm{P}-\mathrm{C}_{i p s o}$ bond reveals that ring exchange in the ground state structure $\mathbf{C}$ needs surmounting an energy barrier of ca. $14 \mathrm{kcal} \cdot \mathrm{mol}^{-1}$ (see SI, p. 16 for details).

With this information in mind, some comments are pertinent regarding the coordination capabilities of the different terphenyl phosphine structural types. Regardless of the nature of $\mathrm{Ar}^{\prime}$, structure $\mathbf{A}$ is readily accessible for dimethylterphenyl phosphines $\mathrm{PMe}_{2} \mathrm{Ar}^{\prime}$. It is of note that for this rather symmetric conformation, the phosphorus lone-pair points to a void region of space with little steric interference from the terphenyl substituents. Classical $P$ coordination is therefore expected, with little or no front-strain ( $F$ strain), ${ }^{34}$ depending upon the nature of the unsaturated transitionmetal Lewis acid centre. As conformations $\mathbf{B}$ and $\mathbf{C}$ can also be readily accessed by these phosphines, other coordination modes involving the $\pi$-system of the proximate aryl ring, i.e. $\kappa-P, \eta^{n}-C_{\text {arene }}$ coordination (see Figure 1), can be foreseen, contingent on metal needs. Contrary to this situation, for bulky phosphines with structure $\mathbf{C}$ the electron density of the phosphorus lone pair faces the nearby aryl ring such that considerable F-strain might arise when bonding to crowded, or relatively crowded, transition-metal fragments. At the same time, this directionality of the lone pair facilitates the formation of complementary $\mathrm{M} \cdots \mathrm{C}_{\text {arene }}$ bonds, that is, once again $\kappa-P, \eta^{n}-C_{\text {arene }}$ binding. As discussed later, these considerations are in excellent agreement with the reactivity found for $\mathrm{PR}_{2} \mathrm{Ar}^{\prime}$ phosphines and $\mathrm{Ni}(\mathrm{CO})_{4}$ as a source of unsaturated "Ni(CO)n" fragments $(n=2,3)$.

Figure 4 contains two views of the molecular structure of $\mathrm{PMe}_{2} \mathrm{Ar}^{\mathrm{Dtbp}}{ }_{2}$, (L1), emphasizing the regular distribution of the $-\mathrm{PMe}_{2}$ half relative to the terphenyl group. Besides other metrics, this is nicely evinced by two almost identical P-Cipso- $\mathrm{C}_{\text {ortho }}$ bond angles of 121.3(2) and 121.4(2) ${ }^{\circ}$. A conspicuous structural feature clearly perceivable in Figure $4 \mathrm{a}$ is the deviation of the flanking aryl ring ipso carbon atoms, $\mathrm{C} 7$ and $\mathrm{C} 21$, by ca. 0.32 and $0.33 \AA$ from the plane of the central aryl ring, with the result of two Me groups of $t$-Bu substituents in opposite rings approaching to a distance of about $4.77 \AA$, only ca. $20 \%$ longer than twice the van der Waals radius of a Me group $(2.0 \AA) .{ }^{41}$ While it is tempting to attribute this distortion to London dispersion forces, ${ }^{17}$ dispersion-corrected DFT-D3 calculations do not support this assumption. Moreover, the unsubstituted terphenyl analogue, $\mathrm{PMe}_{2} \mathrm{Ar}^{\mathrm{Ph}_{2}},(\mathbf{L 1 1})$, exhibits a similar deformation, with deviations of the $\mathrm{C}_{i p s o}$ atoms of about $0.28 \AA$ (Figure S8). It must also be noted that due to the absence of substituents in the ortho positions of the lateral rings, in conformation $\mathbf{A}$ the latter are rotated around the $\mathrm{C}_{\text {ortho }}-\mathrm{C}_{\text {ipso }}$ bond from the almost perpendicular arrangement with respect to the central ring observed in the other two conformations. This results in an angle between the planes containing the lateral rings and the plane of the central ring of $48^{\circ}$ in the structure of $\mathrm{PMe}_{2} \mathrm{Ar}^{\mathrm{Ph}_{2}}$ (vs. an average of $c a .85^{\circ}$ in $\mathrm{PMe}_{2} \mathrm{Ar}^{\mathrm{Xyl_{2 }}}$ ).

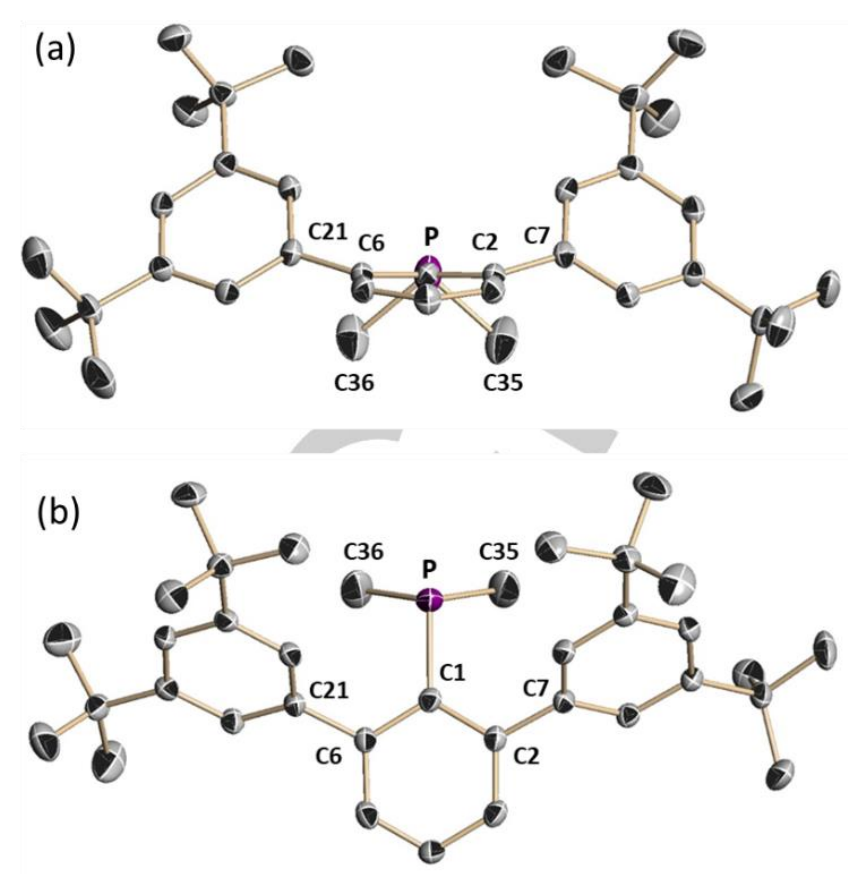

Figure 4. Two views of the molecular structure of $\mathrm{PMe}_{2} \mathrm{Ar}^{\mathrm{Dtbp}} \mathrm{p}_{2}, \mathbf{L 1}$. Selected bond lengths $(\AA)$ and angles $(\stackrel{0}{)})$ : P-C $(1), 1.864(3)$; P-C (35), 1.848(3); P-C (36) 1.851(3); C(36)-P-C(35), 95.2(2); C(35)-P-C(1), 101.4(1); C(36)-P-C(1), 101.9(1); P-C(1)-C(2), 121.3(2); P-C(1)-C(6), 121.4(2).

The molecular structures of $\mathrm{PMe}_{2} \mathrm{ArDipp}_{2}(\mathbf{L 1 4}$, structure of type B) and $\mathrm{PiPr}_{2} \mathrm{Ar}^{\mathrm{Xyl}_{2}}$ (L6, structure C) are illustrated in Figure 5. Xray data for other terphenyl phosphines studied in this work that display structure $\mathbf{B}$ or $\mathbf{C}$ can be found in the Supporting Information (Figures S10-S11). For $\mathrm{PMe}_{2} \mathrm{Ar}^{\mathrm{Dipp}_{2}}$ (Figure 5), one of the P-Me bonds namely $\mathrm{P}-\mathrm{C}(2)$, is near to coplanar with the central aryl ring, with a $\mathrm{C}(\mathrm{Me})-\mathrm{P}-\mathrm{C}_{i p s o}-\mathrm{C}_{\text {ortho }}$ torsion angle of $19.2^{\circ}$. In addition, to attenuate steric repulsions between the $\mathrm{P}$-bonded methyl groups and the adjacent aryl ring, the pertinent $\mathrm{P}-\mathrm{C}_{i p s 0^{-}}$ Cortho bond angle distends to $128.64(9)^{\circ}$ with an accompanying decrease of the other to $113.30(9)^{\circ}$. Molecules of $\mathrm{P}^{\mathrm{P}} \mathrm{Pr}_{2} \mathrm{Ar}^{\mathrm{Xyl}} \mathrm{l}_{2}$ (Figure 5) and of other $i$-propyl-, c-pentyl- and $c$-hexyl-terphenyl phosphines investigated, present also two distinct $\mathrm{P}-\mathrm{C}_{i p s o}-\mathrm{C}_{\text {ortho }}$ bond angles, the wider between ca. 127.5 and $130.6^{\circ}$, and the smaller in the interval 111.6-115.1․ But the prominent structural feature in these bulky phosphines is doubtless the placing of the two $\mathrm{R}$ groups in opposite regions of space relative to the plane of the terphenyl central aryl ring (above and below in the perspective shown in Figure 5). Some steric properties of the terphenyl phosphines in their $\mathrm{Ni}(0)-\mathrm{CO}-\mathrm{PR}_{2} \mathrm{Ar}^{\prime}$ complexes, in particular their angular symmetric deformation coordinate $\mathrm{S} 4$ ' parameters, ${ }^{42}$ will be analysed in the coming section.

Gas-phase, energy-minimized structures of selected terphenyl phosphines were obtained with the aid of DFT calculations. Fair agreement between experimental and calculated geometries was found. Relevant bond distances and angles are collected in Table S1. 


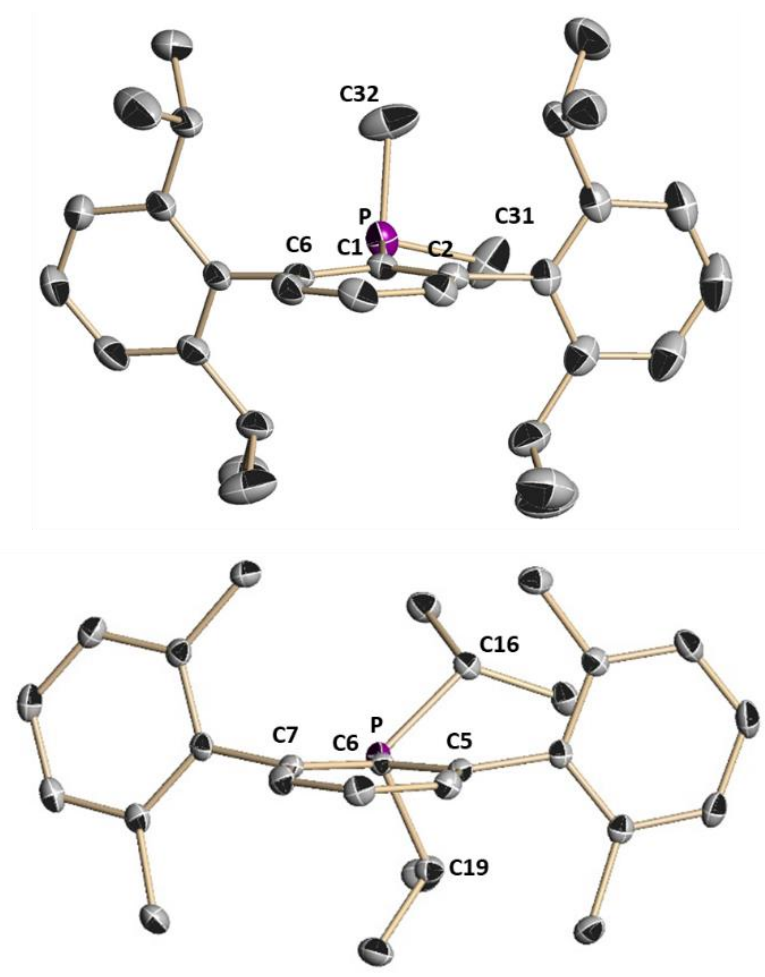

Figure 5. Molecular structures of $\mathrm{PMe}_{2} \mathrm{Ar}^{\mathrm{Dipp}_{2}}$ (L14) (above) and $\mathrm{P}^{\mathrm{i} \mathrm{Pr}_{2} \mathrm{Ar}^{\mathrm{Xyl}}{ }_{2}}$ (L6) (below). Selected bond lengths $(\AA)$ and angles $(\stackrel{\circ}{)})$ : L14: P-C(1), 1.858(1); P$\mathrm{C}(31)$, 1.834(2); P-C(32) 1.839(2); C(31)-P-C(32), 99.29(9); C(31)-P-C(1) 109.54(6); C(32)-P-C(1), 99.61(6); P-C(1)-C(2), 128.64(9); P-C(1)-C(6), 113.30(9) . L6: P-C (6), 1.872(2); P-C(16), 1.882(2); P-C(19), 1.866(2); C(16)-P$\mathrm{C}(19), 104.16(7) ; \mathrm{C}(16)-\mathrm{P}-\mathrm{C}(6), 107.99(6) ; \mathrm{C}(19)-\mathrm{P}-\mathrm{C}(6), 103.69(7) ; \mathrm{P}-\mathrm{C}(6)-$ $\mathrm{C}(5), 129.1(1) ; \mathrm{P}-\mathrm{C}(6)-\mathrm{C}(7), 113.6(1)$.

\section{Dialkylterphenyl Phosphine Nickel Carbonyl Complexes}

We considered of interest ascertaining the electronic properties of dialkylterphenyl phosphines analysing their coordination chemistry towards $\mathrm{Ni}(\mathrm{CO})_{4}$, and studying the resulting $\mathrm{Ni}(0)$ carbonyl-phosphine complexes, $\mathrm{Ni}(\mathrm{CO})_{n}\left(\mathrm{PR}_{2} \mathrm{Ar}^{\prime}\right)$. The bulkiness of $\mathrm{PR}_{2} A r^{\prime}$, as well as the relatively small nickel covalent radius of $1.34 \AA$, ${ }^{43}$ anticipated coordination of only one phosphine per nickel atom. In his pioneering studies, Tolman generated $\mathrm{Ni}(\mathrm{CO})_{3}(\mathrm{~L})$ complexes for a variety of three-coordinate $\mathrm{P}$-donor ligands by the room temperature reaction of $\mathrm{Ni}(\mathrm{CO})_{4}$ and $\mathrm{L}$ in $\mathrm{CH}_{2} \mathrm{Cl}_{2}$, and determined the widely employed Tolman electronic parameter for the ligand $\mathrm{L}, v$ or TEP, as the frequency of the symmetric $A_{1}$ carbonyl stretching mode in the corresponding $\mathrm{Ni}(\mathrm{CO})_{3}(\mathrm{~L})$ species. ${ }^{18,35 a}$ Despite the marked, longstanding impact of this work in organometallic chemistry and catalysis, it is all the more surprising that, as briefly cited, a CSD search (Cambridge Structural Database) revealed $^{36}$ an astonishing scarcity of $\mathrm{X}$-ray data on $\mathrm{Ni}(\mathrm{CO})_{3}\left(\mathrm{PR}_{3}\right)$ complexes of commonly utilized, commercially available alkyl and aryl phosphines. Thus, some ferrocenylphosphine ${ }^{44 a}$ and fluoroalkylphosphine ${ }^{44 \mathrm{~b}} \mathrm{Ni}(\mathrm{CO})_{3}\left(\mathrm{PR}_{3}\right)$ compounds have been characterized, among others, by $\mathrm{X}$-ray crystallography. In addition, carbonylation of a binuclear $\mathrm{Ni}^{-}-\mathrm{Ni}^{l}$ complex of the $p$-terphenyl diphosphine 1,4-bis(2-(diisopropylphosphino)phenyl) benzene, afforded a crystalline material shown by $\mathrm{X}$-ray diffraction ${ }^{45}$ to be a mixture of nickel( 0 ) carbonyls, in which $80 \%$ of the phosphines are bound to $\mathrm{Ni}(\mathrm{CO})_{2}$ and the remaining phosphines to $\mathrm{Ni}(\mathrm{CO})_{3}$.
IR data were not given. Yet, $\mathrm{Ni}(\mathrm{CO})_{3}\left(\mathrm{PR}_{3}\right)$ complexes of $\mathrm{P}^{\mathrm{P}} \mathrm{Pr}_{3}$ $\mathrm{PPh}_{3}, \mathrm{P}\left(c-\mathrm{C}_{6} \mathrm{H}_{11}\right)_{3}$ and other common phosphine derivatives are conspicuously absent, with the relevant exception of $\mathrm{Ni}(\mathrm{CO})_{3}\left(\mathrm{P}^{t} \mathrm{Bu}_{3}\right) \cdot{ }^{44 \mathrm{c}}$ Moreover, attempts to synthesize $\mathrm{Ni}(\mathrm{CO})_{3}(\mathrm{P}(\mathrm{c}-$ $\left.\mathrm{C}_{6} \mathrm{H}_{11}\right)_{2} \mathrm{Ar}$ ) complexes of Buchwald-type biaryl (Ar) phosphines proved unsuccessful, because the ligands appeared to be too sterically demanding to stabilize such complexes. ${ }^{46}$ Recently, the steric and electronic properties of another series of dialkylbiaryl phosphines, $\mathrm{PR}_{2} \mathrm{Ar}{ }^{\mathrm{Ph}}$, were investigated using IR and $\mathrm{X}$-ray data collected for a diversity of $\mathrm{Cr}(0), \mathrm{Pd}(0)$ and $\mathrm{Pd}(\mathrm{II})$ compounds. ${ }^{29 a}$ We found that the target $\mathrm{Ni}(0)-\mathrm{CO}-\mathrm{PR}_{2} \mathrm{Ar}$ ' complexes could be accessed with comparable reaction outcomes either by treatment of $\mathrm{Ni}(\mathrm{CO})_{4}$ with $\mathrm{PR}_{2} \mathrm{Ar}^{\prime}$ or by carbonylation of $1: 1$ mixtures of $\mathrm{Ni}(\operatorname{cod})_{2}$ and $\mathrm{PR}_{2} \mathrm{Ar}^{\prime}$ (cod = 1,5-cyclooctadiene). For convenience, the latter procedure was optimized and employed in all reactions investigated. ${ }^{47}$ The interaction of equimolar mixtures of $\mathrm{Ni}(\mathrm{CO})_{4}$ and $\mathrm{PR}_{2} \mathrm{Ar}^{\prime}$ in THF solution could be readily monitored by IR and ${ }^{31} \mathrm{P}\left\{{ }^{1} \mathrm{H}\right\}$ NMR spectroscopy, showing that depending upon the nature of the phosphine, two types of complexes could form, namely, tricarbonyls $\mathrm{Ni}(\mathrm{CO})_{3}\left(\mathrm{PR}_{2} \mathrm{Ar} r^{\prime}\right)$ (1) or dicarbonyl species $\mathrm{Ni}(\mathrm{CO})_{2}\left(\mathrm{PR}_{2} \mathrm{Ar} r^{\prime}\right)(2)$ (Scheme 3). The two kinds of compound give rise to the expected carbonyl stretching bands, that were registered in the vicinity of $2065\left(A_{1}\right)$ and $1980 \mathrm{~cm}^{-1}$ (E modes) for tricarbonyls 1, and around $1995\left(v_{\text {sym }}\right)$ and $1920\left(v_{\text {asym }}\right)$ for the dicarbonyl complexes 2. Similarly, though ${ }^{31} \mathrm{P}$ NMR chemical shifts for $\mathrm{PR}_{2} \mathrm{Ar}^{\prime}$ depend markedly on the nature of the $\mathrm{R}$ group (Table 1), for compounds 1.PR $\mathbf{P}_{2} \mathbf{A r}$ ' a $\Delta \delta$ shift of ca. $30-40 \mathrm{ppm}$ to higher frequencies relative to the free phosphine was recorded, and of about 40-50 ppm, i.e., an extra $\sim 6-10 \mathrm{ppm}$ shift, for the dicarbonyls $\mathrm{Ni}(\mathrm{CO})_{2}\left(\mathrm{PR}_{2} \mathrm{Ar} \mathrm{r}^{\prime}\right)$. Comparison with $\mathrm{NMR}$ data already in the literature for other transition metal terphenyl phosphine complexes $^{27,28}$ suggests classical P-coordination of the phosphine in $\mathbf{1} \cdot \mathbf{P R}_{\mathbf{2}} \mathbf{A r}$ ' and bidentate binding in $\mathbf{2} \cdot \mathbf{P R}_{\mathbf{2}} \mathbf{A r}$ ', resulting from additional $\mathrm{Ni} \cdots \mathrm{C}_{\text {arene }}$ electronic interactions with the terphenyl substituent. This supposition is supported by X-ray studies and will be discussed later in sufficient detail.

$$
\text { (a) }
$$

Scheme 3. Synthesis of complexes 1·PR $\mathbf{R}_{2} \mathbf{A r}$ ' and 2.PR ${ }_{2} \mathbf{A r}$ '.

As represented in Scheme 3a, only the dimethyl and diethyl terphenyl phosphines, $\mathrm{PMe}_{2} \mathrm{Ar}^{\prime}$ and $\mathrm{PEt}_{2} \mathrm{Ar}^{\prime}$, originated the sought $\mathrm{Ni}(\mathrm{CO})_{3}\left(\mathrm{PR}_{2} \mathrm{Ar} \mathbf{r}^{\prime}\right)$ complexes, 1.PR $\mathbf{A r}$ ', in reactions that took place readily at room temperature and a $\mathrm{CO}$ pressure of 1 bar. Instead, ligands containing the more sterically demanding ${ }^{i} \mathrm{Pr}, \mathrm{C}$ $\mathrm{C}_{5} \mathrm{H}_{9}$ and $c-\mathrm{C}_{6} \mathrm{H}_{11}$ alkyl groups afforded either the dicarbonyl derivatives 2.PR $\mathbf{R}_{2} \mathbf{A r}$ ' of Scheme $3 b$, or non-isolable complexes. In this instance, however, reaction mixtures had to be stirred under vacuum, in many cases at high temperatures (around 
$\left.80^{\circ} \mathrm{C}\right)$. A fair number of $\mathrm{Ni}(\mathrm{CO})_{n}\left(\mathrm{PR}_{2} \mathrm{Ar}{ }^{\prime}\right)(\mathrm{n}=2,3)$ complexes were fully characterized by microanalysis, IR and NMR spectroscopy, and some of them were additionally authenticated by X-ray crystallography. Others were, however, generated in solution for IR spectroscopy studies (Tables 2 and 3 ). The Tolman electronic parameter, TEP, of commercial $\mathrm{P}\left(c-\mathrm{C}_{5} \mathrm{H}_{9}\right)_{3}$ was additionally measured, and for the sake of completeness complex $\mathrm{Ni}(\mathrm{CO})_{3}\left(\mathrm{PPh}_{3}\right)^{48}$ was also prepared and crystallographically characterized. Likewise, two dialkylbiaryl phosphines, specifically $\mathrm{P}\left(c-\mathrm{C}_{6} \mathrm{H}_{11}\right)_{2} \mathrm{Ar}{ }^{\text {Tripp }}$ (XPhos) and $\mathrm{P}^{t} \mathrm{Bu}_{2} \mathrm{Ar}^{\text {Tripp }}$ ('BuXPhos) were examined, and, whereas in accordance with previous studies the latter originated no isolable products, ${ }^{46}$ we were able to characterize a stable $\mathrm{Ni}(\mathrm{CO})_{3}(\mathrm{XPhos})$ complex. Within the series of dicarbonyl derivatives (Scheme $3 b$ ), X-ray studies provided precise details of the unusual nickel coordination environment existing in 2. $\mathbf{P}^{i} \mathrm{Pr}_{2} \mathrm{Ar}^{\mathrm{Dtbp}}{ }_{2}$ and $2 \cdot \mathbf{P}\left(c-\mathrm{C}_{5} \mathrm{H}_{9}\right)_{2} \mathrm{Ar}^{\mathrm{Xyl} \mathbf{l}_{2}}$.

Table 2. IR Wavenumbers $\left(\mathrm{cm}^{-1}\right)$ for the Carbonyl Stretching Vibrations in $\mathrm{Ni}(\mathrm{CO})_{3}\left(\mathrm{PR}_{3}\right)$ complexes in $\mathrm{CH}_{2} \mathrm{Cl}_{2}$ solution.

\begin{tabular}{|c|c|c|c|}
\hline Ligand & Complex & $v_{\operatorname{co}}\left(A_{1}\right)$ & $v_{\operatorname{co}}(E)$ \\
\hline L12 & $\mathrm{Ni}(\mathrm{CO})_{3}\left(\mathrm{PMe}_{2} \mathrm{Ar}^{\mathrm{Xyl}}\right)$ & 2063.8 & 1987 \\
\hline L13 & $\mathrm{Ni}(\mathrm{CO})_{3}\left(\mathrm{PMe}_{2} \mathrm{Ar}^{\mathrm{Mes} 2}\right)$ & 2063 & 1987 \\
\hline L1 & $\mathrm{Ni}(\mathrm{CO})_{3}\left(\mathrm{PMe}_{2} \mathrm{Ar}^{\mathrm{Dtbp} 2}\right)$ & 2063 & 1988 \\
\hline L14 & $\mathrm{Ni}(\mathrm{CO})_{3}\left(\mathrm{PMe}_{2} \mathrm{Ar}^{\mathrm{Dipp} 2}\right)$ & 2062.9 & 1986 \\
\hline L15 & $\mathrm{Ni}(\mathrm{CO})_{3}\left(\mathrm{PMe}_{2} \mathrm{Ar}^{\text {Tripp2 }}\right)$ & 2062 & 1985 \\
\hline L2 & $\mathrm{Ni}(\mathrm{CO})_{3}\left(\mathrm{PEt}_{2} \mathrm{Ar}^{\mathrm{Dtbp} 2}\right)$ & 2061 & 1985 \\
\hline L5 & $\mathrm{Ni}(\mathrm{CO})_{3}\left(\mathrm{P}\left(c-\mathrm{C}_{6} \mathrm{H}_{11}\right)_{2} \mathrm{Ar}^{\mathrm{Dtbp2}}\right)$ & 2060 & $1980^{[b]}$ \\
\hline XPhos & $\mathrm{Ni}(\mathrm{CO})_{3}\left(\mathrm{P}\left(c-\mathrm{C}_{6} \mathrm{H}_{11}\right)_{2} \mathrm{Ar} r^{T r i p p}\right)$ & 2059 & 1980 \\
\hline $\mathrm{P}\left(c-\mathrm{C}_{5} \mathrm{H}_{9}\right)_{3}$ & $\mathrm{Ni}(\mathrm{CO})_{3}\left(\mathrm{P}\left(c-\mathrm{C}_{5} \mathrm{H}_{9}\right)_{3}\right)$ & 2059 & 1980 \\
\hline $\mathrm{P}\left(c-\mathrm{C}_{6} \mathrm{H}_{11}\right)_{3}$ & $\mathrm{Ni}(\mathrm{CO})_{3}\left(\mathrm{P}\left(c-\mathrm{C}_{6} \mathrm{H}_{11}\right)_{3}\right)^{[\mathrm{a}]}$ & 2056.4 & 1973 \\
\hline $\mathrm{P}^{t} \mathrm{Bu}_{3}$ & $\left.\mathrm{Ni}(\mathrm{CO})_{3}\left(\mathrm{P}^{t} \mathrm{Bu}\right)_{3}\right)^{[\mathrm{a}]}$ & 2056.1 & 1971 \\
\hline $\mathrm{PPh}_{3}$ & $\mathrm{Ni}(\mathrm{CO})_{3}\left(\mathrm{PPh}_{3}\right)^{[\mathrm{a}]}$ & 2068.9 & 1990 \\
\hline
\end{tabular}

[a] From ref. 18. [b] Partially obscured band.

Tolman evinced that the symmetric $A_{1}$ mode of the carbonyl ligands in $\mathrm{Ni}(\mathrm{CO})_{3}\left(\mathrm{PR}_{3}\right)$ spanned the range 2056.1 $\left(\mathrm{P}^{t} \mathrm{Bu}_{3}\right)$ to $2011 \mathrm{~cm}^{-1}\left(\mathrm{PF}_{3}\right)$, while the degenerate $\mathrm{E}$ modes were recorded between $1971\left(\mathrm{P}^{t} \mathrm{Bu}_{3}\right)$ and $2016 \mathrm{~cm}^{-1}\left(\mathrm{PCl}_{2} \mathrm{Ph}\right)$ (the figure for $\mathrm{PF}_{3}$ was not given). ${ }^{35 a}$ As represented in Table 2, the new $\mathrm{Ni}(\mathrm{CO})_{3}\left(\mathrm{PR}_{2} \mathrm{Ar}{ }^{\prime}\right)$ complexes featuring a coordinated dimethylterphenyl phosphine ligand are characterized by $A_{1}$ stretching vibrations in the narrow range 2062 to $2064 \mathrm{~cm}^{-1}$, i.e. a few wavenumbers below $\mathrm{PMe}_{2} \mathrm{Ph}\left(2065.3 \mathrm{~cm}^{-1}\right)$ and even slightly down the $\mathrm{PMe}_{3}$ value $\left(2064.1 \mathrm{~cm}^{-1}\right)$. These data confirm the electron-rich nature of $\mathrm{PMe}_{2} \mathrm{Ar}^{\prime}$ ligands, i.e. their overall electrondonor capacity. Similarly, for the $\mathrm{Ni}(\mathrm{CO})_{3}\left(\mathrm{PR}_{2} \mathrm{Ar} \mathrm{r}^{\prime}\right)$ derivatives of $\mathrm{PEt}_{2} \mathrm{Ar}^{\mathrm{Dtbp}}{ }_{2}$ (L2) and $\mathrm{P}\left(c-\mathrm{C}_{6} \mathrm{H}_{11}\right)_{2} \mathrm{Ar}^{\mathrm{Dtbp}}$ (L5), the $\mathrm{A}_{1}$ were registered at 2061 for L2, and 2060 for L5. The above figures for L2 should be compared with the 2063.7 and $1982 \mathrm{~cm}^{-1}$ stretchings found for $\mathrm{PEt}_{2} \mathrm{Ph}^{18}{ }^{18}$ Regarding $\mathrm{P}\left(\mathrm{c}-\mathrm{C}_{6} \mathrm{H}_{11}\right)_{2} \mathrm{Ar}$ ' phosphines, it is noteworthy that the TEP obtained in our work for $\mathrm{Ni}(\mathrm{CO})_{3}\left(\mathrm{P}\left(c-\mathrm{C}_{6} \mathrm{H}_{11}\right)_{2} \mathrm{Ar}^{\text {Tripp }}\right)$ of $2059 \mathrm{~cm}^{-1}$ compares well with that given above for $\mathbf{L} 5$, but it is somewhat higher than the $2054 \mathrm{~cm}^{-1}$ value that was estimated by
Nolan et al. ${ }^{46}$ by linear correlation from $\mathrm{v}(\mathrm{CO})_{\text {average in }}$ $\operatorname{IrCl}(\mathrm{CO})_{2}(\mathrm{XPhos}) .{ }^{49}$ We note further that the TEPs obtained for $\mathrm{P}\left(c-\mathrm{C}_{5} \mathrm{H}_{9}\right)_{2} \mathrm{Ar}^{\mathrm{Dtbp}_{2}}\left(\right.$ L5) , and $\mathrm{P}\left(c-\mathrm{C}_{6} \mathrm{H}_{11}\right)_{2} \mathrm{Ar}^{\text {Tripp }}$ (i.e. XPhos) of 2060 and $2059 \mathrm{~cm}^{-1}$, respectively, are only a few $\mathrm{cm}^{-1}$ higher than for $\mathrm{P}\left(c-\mathrm{C}_{6} \mathrm{H}_{11}\right)_{3}\left(2056.4 \mathrm{~cm}^{-1}\right)$ and comparable to the $2060.6 \mathrm{~cm}^{-1}$ figure that can be calculated for $\mathrm{P}\left(c-\mathrm{C}_{6} \mathrm{H}_{11}\right)_{2} \mathrm{Ph}$ employing Tolman substituent contributions. ${ }^{18}$ The TEP measured in this work for $\mathrm{P}\left(c-\mathrm{C}_{5} \mathrm{H}_{9}\right)_{3}$ is $2059 \mathrm{~cm}^{-1}$.

The symmetric and antisymmetric $\mathrm{v}(\mathrm{CO})$ stretchings found for the formally three-coordinate dicarbonyl complexes 2.PR $\mathbf{A} \mathbf{A r}$ ' can be found in Table S1. Although non-carbonyl-containing, threecoordinate, 16 valence-electron $\mathrm{Ni}(0)$ complexes have long been known, ${ }^{50}$ analogous $\mathrm{CO}$ complexes are very rare and seem to be limited to a few examples encompassing derivatives incorporating strongly nucleophilic carbene ligands (see also reference 45). To the best of our knowledge, truly three-coordinate, 16 valenceelectron $\mathrm{Ni}(\mathrm{CO})_{2}\left(\mathrm{PR}_{3}\right)$ compounds are unknown, and those reported herein constitute no exception, because $\mathrm{X}$-ray studies to be described next unambiguously demonstrate the existence in compounds $\mathbf{2} \cdot \mathbf{P R}_{\mathbf{2}} \mathbf{A r}$ ' of weak $\mathrm{Ni} \cdots \mathrm{C}_{\text {arene }}$ interactions implicating one of the terphenyl flanking aromatic rings. This structural peculiarity limits comparison of IR $v(\mathrm{CO})$ data with four-coordinate $\mathrm{Ni}(\mathrm{CO})_{2}\left(\mathrm{PR}_{3}\right)_{2}$ complexes, and also with the few known examples of three-coordinate $\mathrm{Ni}(\mathrm{CO})_{2}(\mathrm{~L})$ derivatives of carbene ligands. ${ }^{51}$ Notwithstanding these shortcomings, it is appropriate remarking that for the 2.PR $\mathbf{R}_{2} \mathbf{A r}$ ' complexes collected in Table S1, $v_{\text {sym }}$ centres in the proximity of $1995 \mathrm{~cm}^{-1}$ and $v_{\text {asym }}$ at about $1923 \mathrm{~cm}$ 1 , values comparable to the 1990 and 1926 wavenumbers characteristic of the four-coordinate, bis- $\mathrm{PMe}_{3}$ complex $\mathrm{Ni}(\mathrm{CO})_{2}\left(\mathrm{PMe}_{3}\right)_{2}$. With due caution, given the different nature of the compounds, the IR properties of complexes 2.PR $\mathbf{R}_{2} \mathbf{A r}$ ' reflect the high metal basicity of their $\left[\mathrm{Ni}\left(\kappa-P, \eta^{2}-\mathrm{C}_{\text {arene }}-\mathrm{PR}_{2} \mathrm{Ar} \mathrm{r}^{\prime}\right)\right]$ metal fragment.

We have studied the solution dynamic behaviour of 2. $\mathrm{P}^{\mathrm{P}} \mathrm{Pr}_{2} \mathrm{Ar}^{\mathrm{Dtbp} 2}$ by variable temperature NMR spectroscopy. Two intramolecular rearrangements can be envisioned. First, interchange of the two degenerate $\eta^{2}$-structures, each involving the ipso and one of the ortho carbon atoms of the Dtbp ring engaged in nickel bonding, through a $\kappa-P, \eta^{1}-\mathrm{C}_{i p s o}$ transition state (see Scheme 4), is expected to be fast (only $1.7 \mathrm{kcal} \cdot \mathrm{mol}^{-1}$ energy barrier according to DFT calculations), generating an effective plane of symmetry containing the terphenyl central ring and the $\mathrm{Ni}-\mathrm{P}$ bond. Second, since a relatively weak $\mathrm{Ni}-\eta^{2}-\mathrm{C}_{\text {arene }}$ bonding interaction is foreseeable (vide infra), temporary cleavage of the $\mathrm{Ni}-\eta^{2}$-Dtbp linkage to form a truly three-coordinate $\mathrm{Ni}(\mathrm{CO})_{2}\left(\mathrm{PiPr}_{2} \mathrm{Ar}^{\mathrm{Dtbp}}{ }_{2}\right)$ intermediate or transition state, followed by rotation around the $\mathrm{C}_{i p s o}-\mathrm{P}$ bond would result in the shuffle of the two Dtbp units.

In the room temperature ${ }^{1} \mathrm{H}$ NMR spectrum of complex 2. $\mathbf{P}^{i} \mathrm{Pr}_{2} \mathrm{Ar}^{\mathrm{Dtbp}_{2}}$ the two isopropyl groups of the phosphine ligand are equivalent and originate a multiplet centred at $1.94 \mathrm{ppm}(2 \mathrm{H}$, doublet of septets, ${ }^{2} J_{\mathrm{HP}}=13.3,{ }^{3} \mathrm{JHH}_{\mathrm{HH}}=6.6 \mathrm{~Hz}$ ) accompanied by another, also well-defined multiplet spanning across the 0.92-0.84 ppm interval $\left(6 \mathrm{H}+6 \mathrm{H}\right.$; $\left.{ }^{3} J_{\mathrm{HP}}=10.4,9.4 \mathrm{~Hz}\right)$. In like manner, a doublet ${ }^{13} \mathrm{C}$ NMR resonance arises at $198.9 \mathrm{ppm}\left({ }^{2} \mathrm{~J}_{\mathrm{CP}}=10 \mathrm{~Hz}\right)$ due to two equivalent carbonyl ligands. It is therefore evident that the first of the aforementioned dynamic processes, namely, interconversion of the two equivalent $\kappa-P, \eta^{2}-C_{\text {arene }}$ structures, occurs in a swift manner under ambient conditions. In contrast, the ${ }^{t} \mathrm{Bu}$ protons of the two lateral rings remain inequivalent at room temperature and are seen in the form of a broad resonance at 


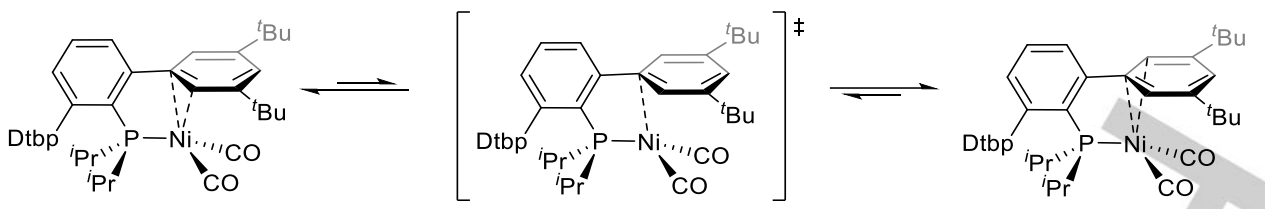

Scheme 4. Solution dynamic behaviour of $2 \cdot \mathbf{P}_{\mathbf{P r}_{2}} \mathbf{A r}^{\mathrm{Dtbp}}{ }^{2}$ exchanging degenerate $\mathrm{Ni}-\eta^{2}-\mathrm{C}_{\text {arene }}$ structures.

around $1.39 \mathrm{ppm}$. Nevertheless, this signal resolves in two singlets at 1.36 and $1.39 \mathrm{ppm}(18 \mathrm{H}, 18 \mathrm{H})$ on cooling at $-30^{\circ} \mathrm{C}$. As this change is not accompanied by noticeable variations of the ${ }^{1} \mathrm{H}$ NMR resonances of the $-\mathrm{P}^{\mathrm{P}} \mathrm{Pr}_{2}$ moiety, in all probability it can be proposed to be due to significantly slowed down commuting of the Dtbp rings, and hence to attainment at low temperatures of a static structure in which the phosphine coordination mode is akin to that found in the solid state. From the value of the rate constant for exchange determined at the coalescence temperature of $c a$. $15^{\circ} \mathrm{C}$, an energy barrier $\Delta \mathrm{G}^{\ddagger} \approx 15 \mathrm{kcal} \cdot \mathrm{mol}^{-1}$ can be estimated ${ }^{52}$ for the flipping of the terphenyl flanking rings. DFT calculations on this process are in accordance with this value (see $\mathrm{SI}$ ).

To attain unambiguous, definitive structural information on the nickel carbonyl terphenyl phosphine complexes, 1·PR $\mathbf{A r}$ ' and 2. $\mathbf{P R}_{2} \mathbf{A r}$ ', single crystals suitable for $X$-ray studies were grown for some of these compounds. Concretely, the tricarbonyl derivatives of $\mathrm{PMe}_{2} \mathrm{Ar}^{\mathrm{Xyl} l_{2}}, \mathrm{PMe}_{2} \mathrm{Ar}^{\mathrm{Dipp} 2}$ and $\mathrm{PMe}_{2} \mathrm{Ar}^{\mathrm{Dtbp}}{ }_{2}$, as well as the dicarbonyls $\mathrm{Ni}(\mathrm{CO})_{2}\left(\mathrm{PiPr}_{2} \mathrm{Ar}^{\mathrm{Dtbp}} 2\right)$ and $\mathrm{Ni}(\mathrm{CO})_{2}\left(\mathrm{P}\left(c-\mathrm{C}_{5} \mathrm{H}_{9}\right)_{2} \mathrm{Ar}^{\mathrm{Xyl} \mathrm{l}_{2}}\right)$, were crystallographically characterized. For comparative purposes, the structure of the known $\mathrm{Ni}(\mathrm{CO})_{3}\left(\mathrm{PPh}_{3}\right),{ }^{48}$ was likewise determined (Figure S12).

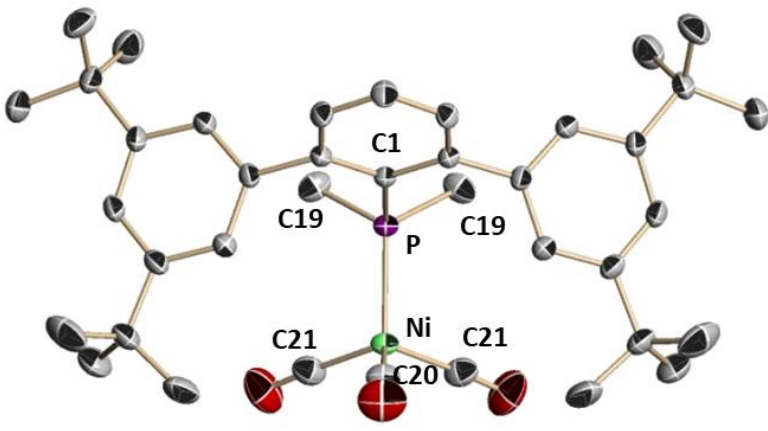

$\mathrm{Ni}(\mathrm{CO})_{3}\left(\mathrm{PMe}_{2} \mathrm{Ar}^{\mathrm{Dtbp} 2}\right)$

Figure 6. Molecular structure of tricarbonyl $\mathrm{Ni}(\mathrm{CO})_{3}\left(\mathrm{PMe}_{2} \mathrm{Ar}^{\mathrm{Dtbp} 2}\right)$ (1.L1). Selected bond lengths $(\AA)$ and angles $\left({ }^{\circ}\right): \mathrm{Ni}-\mathrm{P}, 2.2401(7) ; \mathrm{Ni}-\mathrm{C}(21), 1.797(3)$; $\mathrm{Ni}-\mathrm{C}(20), 1.782(3) ; \mathrm{P}-\mathrm{C}(1), 1.861(3)$; P-C(19), 1.832(2); C(19)-P-C(19), $97.2(2)$; $C(19)-P-C(1), 105.38(9)$.

As illustrated in Figures 6 and S12, the three tricarbonyls investigated feature the expected, somewhat distorted tetrahedral geometry around the metal centre. A conspicuous structural feature is the common conformation of type $\mathbf{A}$ (Figure 3 ) adopted by the phosphine in these complexes. As can be seen, not only the two P-Me bonds occupy the same region of space relative to the plane of the terphenyl central aryl ring, but moreover the $\mathrm{PMe}_{2}$ moiety is symmetrically disposed with respect to this ring such that the two $\mathrm{P}-\mathrm{C}_{i p s o}-\mathrm{C}_{\text {ortho }}$ angles are practically identical (ca. $121^{\circ}$ in the three complexes). As free, non-coordinated molecules, only $\mathrm{PMe}_{2} \mathrm{Ar}$ ' adopts a conformation alike $\mathbf{A}$, inasmuch as $\mathrm{PMe}_{2} \mathrm{Ar}^{\mathrm{Xy} l_{2}}$ and $\mathrm{PMe}_{2} \mathrm{Ar}^{\mathrm{Dipp}_{2}}$ prefer a structure of type $\mathbf{B}$. In view of the meagre differences in energy between conformations $\mathbf{A}$ and $\mathbf{B}$ in the free phosphines, it seems plausible that to attenuate $\mathrm{F}$ strain between the $\mathbf{B}$ phosphine conformation and the $\mathrm{Ni}(\mathrm{CO})_{3}$ fragment in the $\mathrm{Ni}(\mathrm{CO})_{3}\left(\mathrm{PMe}_{2} \mathrm{Ar} r^{\prime}\right)$ complex, conformation $\mathbf{A}$ becomes favoured. As mentioned earlier, in conformation $\mathbf{A}$ the phosphorus lone pair points towards an unoccupied region of space, whereas B-type complexation would place the $\mathrm{Ni}(\mathrm{CO})_{3}$ moiety relatively close to one of the flanking aryl rings of the terphenyl substituent.
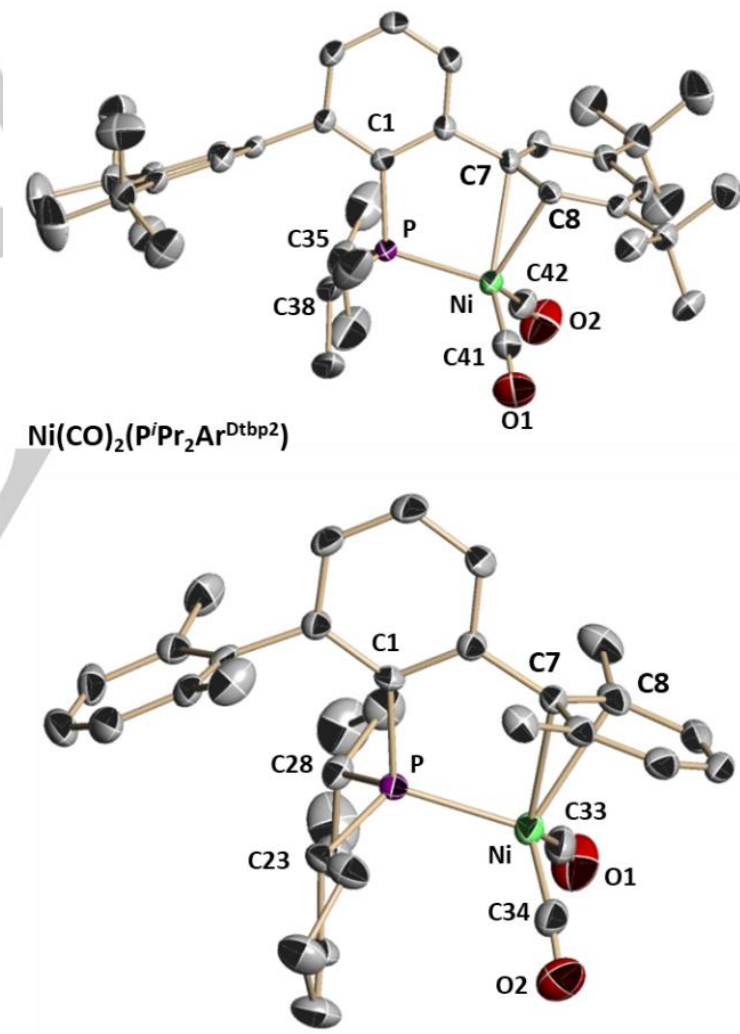

$\mathrm{Ni}(\mathrm{CO})_{2}\left(\mathrm{P}\left(\mathrm{c}-\mathrm{C}_{5} \mathrm{H}_{9}\right)_{2} \mathrm{Ar}^{\mathrm{Xy}}{ }^{\mathrm{I}}\right)$

Figure 7. Molecular structures of dicarbonyls $\left(\mathrm{Ni}(\mathrm{CO})_{2}\left(\mathrm{PiPr}_{2} \mathrm{Ar}^{\mathrm{Dtbp} 2}\right)(\mathbf{2} \cdot \mathrm{L3})\right.$ and $\mathrm{Ni}(\mathrm{CO})_{2}\left(\mathrm{P}\left(c-\mathrm{C}_{5} \mathrm{H}_{9}\right)_{2} \mathrm{Ar}^{\mathrm{Xy} / 2}\right)(\mathbf{2} \cdot \mathbf{L} 7)$. Selected bond lengths $(\AA)$ and angles $\left({ }^{\circ}\right): \mathbf{2} \cdot \mathbf{L} 3$ : $\mathrm{Ni}-\mathrm{P}, 2.2056(6)$; Ni-C(41), 1.763(3); Ni-C(42), 1.776(3); Ni-C(7), 2.449(2); Ni$\mathrm{C}(8), 2.332(2) ; \mathrm{P}-\mathrm{C}(1), 1.849(2)$; P-C(35), 1.863(3); P-C(38), 1.848(3); C(35)-PC(38), 106.1(2); C(35)-P-C(1), 104.0(1); C(38)-P-C(1), 104.5(1). 2.L7: Ni-P, 2.2037(8); Ni-C(33), 1.767(4); Ni-C(34), 1.770(4); Ni-C(7), 2.438(3); Ni-C(8), 2.414(3); P-C(1), 1.850(2); P-C(23), 1.845(3); P-C(28), 1.845(3); C(23)-P-C(28), 104.2(1); C(23)-P-C(1), 107.7(1); C(28)-P-C(1), 104.3(1). 
A comparison of selected bond distances and angles for compounds 1.PR $\mathbf{P}_{2} \mathbf{A r}$ ' and related $\mathrm{Ni}(\mathrm{CO})_{3}(\mathrm{~L})$ structures is given in Table 3. The Ni-P distances in 1.PMe $\mathbf{A r}^{\mathrm{Xyl_{2 }}}$ and 1.PMe $\mathbf{A r}^{\mathrm{Dtbp}}$ are very similar $(2.248(1)$ and $2.240(1) \AA)$ and comparable to that

Table 3. Selected Structural Data for $\mathrm{Ni}(\mathrm{CO})_{3}(\mathrm{~L})$ and $\mathrm{Ni}(\mathrm{CO})_{2}(\mathrm{~L})$ complexes of tertiary phosphine and nucleophilic carbene ligands.

\begin{tabular}{|c|c|c|c|c|c|}
\hline Ligand & Complexes & $\mathrm{Ni}-\mathbf{P}(\mathrm{A})$ & $\mathrm{Ni}-\mathrm{CO}$ (average, $\AA$ ) & $\sum \mathrm{C}-\mathrm{P}-\mathrm{C}\left({ }^{\circ}\right)$ & $S 4^{\prime}\left({ }^{\circ}\right)$ \\
\hline L1 & $\mathrm{Ni}(\mathrm{CO})_{3}\left(\mathrm{PMe}_{2} \mathrm{Ar}^{\mathrm{Dtbp} 2}\right)$ & 2.240 & 1.792 & 308.0 & 38.0 \\
\hline L12 & $\mathrm{Ni}(\mathrm{CO})_{3}\left(\mathrm{PMe}_{2} \mathrm{Ar}^{\mathrm{Xyl} \mathrm{2}}\right)$ & 2.248 & 1.780 & 311. & 31.5 \\
\hline L14 & $\mathrm{Ni}(\mathrm{CO})_{3}\left(\mathrm{PMe}_{2} \mathrm{Ar} r^{\mathrm{Dipp} 2}\right)$ & 2.294 & 1.776 & 315 & 24.4 \\
\hline $\mathrm{PPh}_{3}$ & $\mathrm{Ni}(\mathrm{CO})_{3}\left(\mathrm{PPh}_{3}\right)$ & 2.224 & 1.800 & 308.7 & 37.5 \\
\hline $\mathrm{P}^{t} \mathrm{Bu}_{3}{ }^{[\mathrm{a}]}$ & $\mathrm{Ni}(\mathrm{CO})_{3}\left(\mathrm{P}^{t} \mathrm{Bu}_{3}\right)$ & 2.289 & 1.721 & 323.4 & 12.9 \\
\hline $\mathbf{I P r ^ { [ b ] }}$ & $\mathrm{Ni}(\mathrm{CO})_{3}(\mathrm{IPr})$ & 1.979 & 1.792 & & \\
\hline CAAC Methyl[c] & $\mathrm{Ni}(\mathrm{CO})_{3}\left(\mathrm{CAAC}^{\text {Methyl }}\right)$ & 1.963 & 1.800 & & \\
\hline L3 & $\mathrm{Ni}(\mathrm{CO})_{2}\left(\mathrm{P}^{\mathrm{i}} \mathrm{Pr}_{2} \mathrm{Ar}^{\mathrm{Dtbp} 2}\right)$ & 2.206 & 1.769 & 314.6 & 26.0 \\
\hline L7 & $\mathrm{Ni}(\mathrm{CO})_{2}\left(\mathrm{P}\left(\mathrm{c}-\mathrm{C}_{5} \mathrm{H}_{9}\right)^{i} \mathrm{Pr}_{2} \mathrm{Ar}^{\mathrm{Xyl} / 2}\right)$ & 2.204 & 1.770 & 316.2 & 23.4 \\
\hline $\operatorname{IAd}^{[\mathrm{a}]}$ & $\mathrm{Ni}(\mathrm{CO})_{2}(\mathrm{IAd})$ & $1.96^{[\mathrm{d}]}$ & 1.760 & & \\
\hline$I^{t} B u^{[b]}$ & $\mathrm{Ni}(\mathrm{CO})_{2}\left(\mathrm{I}^{t} \mathrm{Bu}\right)$ & $1.96^{[\mathrm{d}]}$ & 1.751 & & \\
\hline $\mathrm{C}\left(\mathrm{PPh}_{3}\right)_{2} \mathrm{e}^{[\mathrm{e}]}$ & $\mathrm{Ni}(\mathrm{CO})_{2}\left(\mathrm{C}\left(\mathrm{PPh}_{3}\right)_{2}\right)$ & $1.99^{[d]}$ & 1.746 & & \\
\hline
\end{tabular}

[a] Ref. 44c. [b] Ref. 51b. [cb] Ref. 51c. [d] d(Ni-C Carbene). [e] Ref. 51a

in $\mathrm{Ni}(\mathrm{CO})_{3}\left(\mathrm{PPh}_{3}\right)$, the latter being equal to $2.235(1) \AA$. The most sterically demanding of the three phosphines, $\mathrm{PMe}_{2} \mathrm{Ar}^{\mathrm{Dipp}_{2}}$, forms the longest $\mathrm{Ni}-\mathrm{P}$ bond in this series at 2.294(2) $\AA$. Referring to Ni$\mathrm{CO}$ bond distances, which for the three complexes studied cluster around $1.78 \AA$, it is hardly surprising that they are shorter than in $\mathrm{Ni}(\mathrm{CO})_{4}$ (ca. $1.82 \AA$ ) and comparable to those in $\mathrm{Ni}(\mathrm{CO})_{3}(\mathrm{~L})$ complexes containing $\mathrm{PPh}_{3}, \mathrm{~N}$-heterocyclic carbenes $(\mathrm{NHC})$ or cyclic (alkyl)(amino)carbenes (CAAC) ligands (Table 4). ${ }^{51}$ Probably, the length of the $\mathrm{Ni}-\mathrm{CO}$ bonds in these complexes is more a reflection of the sterics than of the electron density at the $\mathrm{Ni}(0)$ centre. The $\mathrm{C}-\mathrm{O}$ distances, with values of approximately $1.14 \AA$, are also unexceptional and of scant structural utility, because, as stated by Cotton and Wilkinson, ${ }^{53}$ in the 2-3 bond order range concerned, the $\mathrm{CO}$ bond length is relatively insensitive to bond order.

For the three 1.PMe $\mathbf{P r}_{2}$ ' complexes investigated, the sum of the C-P-C bond angles is approximately $10^{\circ}$ larger than for the free ligands and amounts to $315.7(3)^{\circ}\left(\mathrm{PMe}_{2} \mathrm{Ar}^{\mathrm{Dipp}}{ }_{2}\right), 311.1(3)^{\circ}$ $\left(\mathrm{PMe}_{2} \mathrm{Ar}^{\mathrm{Xyl}}\right)$ and $308.0(2)^{\circ}\left(\mathrm{PMe}_{2} \mathrm{Ar}^{\mathrm{Dtbp}}{ }^{\circ}\right)$. The values of the angular symmetric deformation coordinate S4' for the phosphine ligands in complexes 1.PR $\mathbf{P}_{\mathbf{2}} \mathbf{A r}$ ' are also included in Table $3 .{ }^{42} \mathrm{It}$ is worth recalling that $\mathrm{PMe}_{3}, \mathrm{PPh}_{3}$ and $\mathrm{P}^{t} \mathrm{Bu}_{3}$ possess mean S4 parameters of $46.5,27.6$ and $2.6^{\circ}$, respectively, and that $S 4$ values for a given phosphine may span a considerable wide range ${ }^{42}$ Consequently, it is best to compare series of related complexes. A recent study based on trans- $\mathrm{PdCl}_{2}\left(\mathrm{PR}_{3}\right)_{2}$ complexes provided S4' values for Buchwald-type dialkylbiaryl phosphines, $\mathrm{PR}_{2} \mathrm{Ar}^{\mathrm{Ph}_{2}}$, of ca. $28^{\circ}(\mathrm{R}=\mathrm{Me}), 29.3^{\circ}(\mathrm{Et}), 29.8^{\circ}(\mathrm{Ph})$ and $16.9\left(c-\mathrm{C}_{6} \mathrm{H}_{11}\right) \cdot{ }^{29 a}$ Corresponding parameters for $\mathrm{PMe}_{3}$, $\mathrm{PMe}_{2} \mathrm{Ph}$ and $\mathrm{P}^{\mathrm{B}} \mathrm{Bu}_{2} \mathrm{Ph}$ in these complexes were 35.3, 32.8 and $18.4^{\circ}$, respectively. As shown in Table $3, \mathrm{X}$-ray data for the $\mathrm{Ni}(\mathrm{CO})_{3}\left(\mathrm{PR}_{3}\right)$ complexes discussed in this work lead to S4'values of $38.0^{\circ}\left(\mathrm{PMe}_{2} \mathrm{Ar}^{\mathrm{Dtbp}} 2\right), 31.5^{\circ}\left(\mathrm{PMe}_{2} \mathrm{Ar}^{\mathrm{Xyl}}\right)$ and $24.4^{\circ}\left(\mathrm{PMe}_{2} \mathrm{Ar}^{\mathrm{Dipp}}{ }^{2}\right)$ in what refers to terphenyl phosphines, and of $37.5^{\circ}$ for $\mathrm{PPh}_{3}$ and
13.0 for $\mathrm{P}^{t} \mathrm{Bu}_{3}$. Clearly, the steric demands of our terphenyl phosphines are significantly smaller than for $\mathrm{P}^{t} \mathrm{Bu}_{3}$, and in comparison with $\mathrm{PPh}_{3}, \mathrm{PMe}_{2} \mathrm{Ar}^{\mathrm{Dtbp}}$ is equivalent and $\mathrm{PMe}_{2} \mathrm{Ar}^{\mathrm{Xy} l_{2}}$ and $\mathrm{PMe}_{2} \mathrm{Ar}^{\mathrm{Dipp} 2}$ increasingly larger.

As already noted, $\mathrm{PR}_{2} \mathrm{Ar}^{\prime}$ phosphines containing the sterically demanding $\operatorname{Pr}, c-\mathrm{C}_{5} \mathrm{H}_{9}$ and $c-\mathrm{C}_{6} \mathrm{H}_{11}$ alkyl groups did not provide isolable $\mathrm{Ni}(\mathrm{CO})_{3}\left(\mathrm{PR}_{2} \mathrm{Ar} r^{\prime}\right)$ complexes, although for $\mathrm{P}(c$ $\left.\mathrm{C}_{6} \mathrm{H}_{11}\right)_{2} \mathrm{Ar}^{\mathrm{Dtbp}} 2$ minor amounts of the tricarbonyl derivative accompanied the major dicarbonyl reaction product. Once again, it should be recalled that the very bulky $\mathrm{PR}_{2} \mathrm{Ar}^{\prime}$ phosphines adopt a structure of type $\mathbf{C}$ (Figure 3 ) with the phosphorus lone pair facing the $\pi$ system of one of the side aromatic rings, as found earlier for dialkylbiaryl phosphines. ${ }^{40}$ Under these circumstances, it is reasonable to surmise that $\mathrm{F}$-strain between the phosphine and $\mathrm{Ni}(\mathrm{CO})_{3}$ fragment destabilizes the purported $\mathrm{Ni}(\mathrm{CO})_{3}\left(\mathrm{PR}_{2} \mathrm{Ar}{ }^{\prime}\right)$ complexes and promotes formation of dicarbonyls 2. $\mathbf{P R}_{2} \mathbf{A r}$ ' (see Supporting Information, p. 18).

$\mathrm{X}$-ray studies on complexes $\mathrm{Ni}(\mathrm{CO})_{2}\left(\mathrm{Pi}^{\mathrm{P}} \mathrm{Pr}_{2} \mathrm{Ar}^{\mathrm{Dtbp}}{ }_{2}\right)$ and $\mathrm{Ni}(\mathrm{CO})_{2}\left(\mathrm{P}\left(c-\mathrm{C}_{5} \mathrm{H}_{9}\right)_{2} \mathrm{Ar}^{\mathrm{Xyl} 2}\right)$ demonstrate that their seemingly unsaturated, three-coordinate structure corresponds in fact to four-coordinated nickel centres, as in each complex there is a relatively weak $\mathrm{Ni}-\eta^{2}-\mathrm{C}_{\text {arene }}$ interaction with one of the Dtbp or Xyl substituents (Figure 7). The molecules of these complexes have in the solid state a very uncommon oblique triangular pyramidal geometry in which one of the $\mathrm{C}_{i p s o}-\mathrm{C}_{\text {ortho }}$ bonds of the proximal lateral ring occupies the apex. The electronic interaction with the flanking ring is undoubtedly weak, ${ }^{54}$ as it is characterized by fairly long $\mathrm{Ni} \cdots \mathrm{C}_{\text {arene }}$ distances. For example, in the Xyl-substituted $\mathrm{Ni}(\mathrm{CO})_{2}\left(\mathrm{P}\left(c-\mathrm{C}_{5} \mathrm{H}_{9}\right)_{2} \mathrm{Ar}^{\mathrm{Xyl}}\right)$ complex, where the nickel atom interacts with one of the $\mathrm{C}_{i p s o}=\mathrm{C}(\mathrm{Me})$ bonds of a lateral ring, the two Ni-C bond distances are equal to ca. 2.44 (to C7) and $2.41 \AA$ (to C8), both standing well above the $1.97 \AA$ value of the sum of the covalent radii of $\mathrm{C}_{\mathrm{sp}^{2}}(0.73 \AA)$ and $\mathrm{Ni}(1.24 \AA) .{ }^{43}$ Complex $\mathrm{Ni}(\mathrm{CO})_{2}\left(\mathrm{P}^{\mathrm{P}} \mathrm{Pr}_{2} \mathrm{Ar}^{\mathrm{Dtbp}}\right)$ possesses no substituents at the ortho 
carbon atoms of the Dtbp ring, which causes the $\mathrm{Ni} \cdots \mathrm{C}_{\text {ortho }}$ distance (to C8, Figure 7) to be somewhat shorter at 2.332(2) $\AA$, while the other to $C_{i p s o}(C 7)$ remains long at 2.449(2) $\AA$. Yet, the $\mathrm{Ni} \cdots \mathrm{C}_{\text {arene }}$ distances in complexes $\mathbf{2} \cdot \mathbf{P R}_{\mathbf{2}} \mathbf{A r}$ ' are significantly longer than in known $\mathrm{Ni}(0)$-olefin complexes. For example, $\mathrm{Ni}(\mathrm{cod})_{2}$ exhibits $\mathrm{Ni}-\mathrm{C}$ bond lengths in the range 2.11-2.13 $\AA$, $55 \mathrm{a}$ and in $\mathrm{Ni}\left(\mathrm{C}_{2} \mathrm{H}_{4}\right)_{2}\left(\mathrm{PPh}_{3}\right)$ the $\mathrm{Ni}-\mathrm{C}$ distances are close to $2.0 \AA .{ }^{55 b}$ The weakness of the $\mathrm{Ni}-\eta^{2}-\mathrm{C}_{\text {arene }}$ bond denoted by these metrics is congruent with the facile solution exchange of the coordinated and free Dtbp rings measured, as discussed earlier, by variable temperature ${ }^{1} \mathrm{H}$ NMR spectroscopy for $\mathrm{Ni}(\mathrm{CO})_{2}\left(\mathrm{P}^{\mathrm{i}} \mathrm{Pr}_{2} \mathrm{Ar}^{\mathrm{Dtbp} 2}\right)$. Recall that the $\Delta G^{\ddagger}$ value for exchange calculated from the rate constant at the coalescence temperature of $15^{\circ} \mathrm{C}$ is of ca. 15 $\mathrm{kcal} \cdot \mathrm{mol}^{-1}$. It is thus clear that complexes $\mathbf{2} \cdot \mathbf{P} \mathbf{R}_{2} \mathbf{A r}$ ' may be viewed as a source of unsaturated, three-coordinate, sixteen valence electron species.

To complete our study devoted to nickel carbonyls containing terphenyl phosphine ligands, we essayed their capacity to undergo oxidative addition reactions. ${ }^{51}$ Room temperature addition of 4-bromotoluene to $\mathrm{Ni}(\mathrm{CO})_{3}\left(\mathrm{PMe}_{2} \mathrm{Ar}^{\mathrm{Dtbp}}{ }_{2}\right)$, $\mathrm{Ni}(\mathrm{CO})_{3}\left(\mathrm{PMe}_{2} \mathrm{Ar}^{\mathrm{Dipp}}{ }_{2}\right)$ and $\mathrm{Ni}(\mathrm{CO})_{2}\left(\mathrm{P}^{\mathrm{P}} \mathrm{Pr}_{2} \mathrm{Ar}^{\mathrm{Dtbp}}\right)$ gave no observable chemical changes, though upon heating at temperatures around $70^{\circ} \mathrm{C}$ decomposition occurred with formation of metallic nickel. Attempts to oxidatively add Mel to the above dicarbonyls were also fruitless. Despite these failures, the two tricarbonyls $\mathrm{Ni}(\mathrm{CO})_{3}\left(\mathrm{PMe}_{2} \mathrm{Ar}^{\mathrm{Dtbp}} 2\right)$ and $\mathrm{Ni}(\mathrm{CO})_{3}\left(\mathrm{PEt}_{2} \mathrm{Ar}^{\mathrm{Dtbp}}\right)$ experienced smooth room temperature reactions with 3-bromo-1propene (Scheme 5). These occurred with displacement of the carbonyl ligands and formation of the $\mathrm{Ni}(\mathrm{II}) \eta^{3}$-allyl compounds $\mathrm{Ni}\left(\mathrm{n}^{3}-\mathrm{C}_{3} \mathrm{H}_{5}\right) \mathrm{Br}\left(\mathrm{PR}_{2} \mathrm{Ar}^{\mathrm{Dtbp}}\right)$, as the only organometallic products (Scheme $5 \mathrm{a}$ ). Characterization of the nickel allyls by elemental analysis and NMR studies fully supports the proposed formulation (see the Supporting Information). For instance, ${ }^{31} \mathrm{P}\left\{{ }^{1} \mathrm{H}\right\}$ NMR singlets appear with chemical shifts $-2.5\left(\mathrm{PMe}_{2} \mathrm{Ar}^{\mathrm{Dtbp}}{ }_{2}\right)$ and 23.2 $\mathrm{ppm}\left(\mathrm{PEt}_{2} \mathrm{Ar}^{\mathrm{Dtbp}_{2}}\right)$, therefore with $\Delta \delta$ values of $c a .34$ and $36 \mathrm{ppm}$, respectively, relative to the free phosphine ligands. The two complexes were isolated as orange solids, soluble in $\mathrm{C}_{6} \mathrm{H}_{6}$ and other aromatic hydrocarbons. In contrast, the analogous reaction of $\mathrm{Ni}(\mathrm{CO})_{2}\left(\mathrm{PiPr}_{2} \mathrm{Ar}^{\mathrm{Dtbp}}\right)$ with allyl bromide resulted in the formation of a bluish green solid, insoluble in benzene, but soluble in the more polar acetone or acetonitrile solvents. These and other properties suggest the salt-like formulation presented in Scheme $5 \mathrm{~b}$, based on the allyl phosphonium cation $\left[\mathrm{P}\left(\mathrm{C}_{3} \mathrm{H}_{5}\right)^{i} \mathrm{Pr}_{2}\left(\mathrm{Ar}^{\mathrm{Dtbp}}\right)\right]^{+}$ and a tribromonickelate anion, $\mathrm{NiBr}_{3}{ }^{-}$. This proposal finds support in elemental analysis and ESMS, as well as in NMR spectra recorded for the phosphonium cation. We did not consider necessary the definitive structural characterization of the $\mathrm{NiBr}_{3}$ anion. ${ }^{56}$

(a)

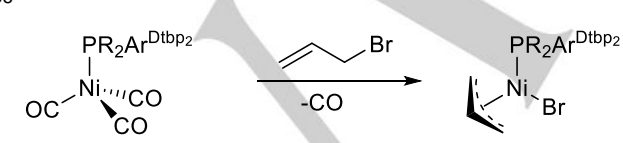

$$
\mathrm{R}=\mathrm{Me}, \mathrm{Et}
$$

(b)

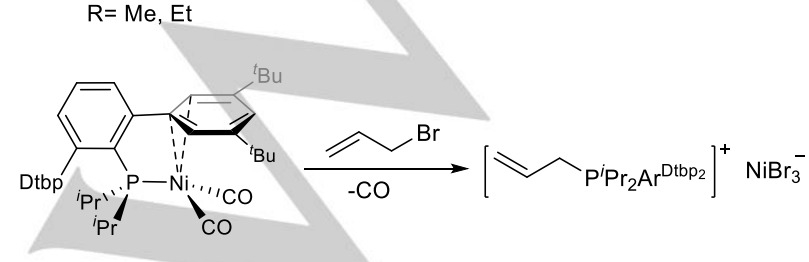

Scheme 5. Reactivity of the nickel carbonyl complexes towards oxidative addition of allyl bromide.

\section{Conclusions}

The experiments and theoretical calculations described in foregoing sections lead to the conclusion that dialkylterphenyl phosphines, $\mathrm{PR}_{2} \mathrm{Ar}^{\prime}$, adopt in the solid state one of the three structures $\mathbf{A}, \mathbf{B}$ or $\mathbf{C}$, represented in Figure 3. For a given phosphine, the structural choice is contingent upon the importance of: (i) steric repulsions among the two $\mathrm{R}$ and the Ar' phosphorus substituents, with a strong influence of alkyl groups occupying the 2,6-positions of the lateral rings (Me or ${ }^{\mathrm{P}} \mathrm{Pr}$ in this work), and (ii) electron-electron repulsions between the phosphorus lone pair and the $\pi$-system of the nearby ring. All the $\mathrm{PMe}_{2} \mathrm{Ar}^{\prime}$ phosphines presently known feature structures of type $\mathbf{A}$ or $\mathbf{B}$, for which energy differences appear to be small. Conformation $\mathbf{C}$ is also readily accessible. On the contrary, the bulkier $\mathrm{P}^{\prime} \mathrm{Pr}_{2} \mathrm{Ar} r^{\prime}, \mathrm{P}\left(c-\mathrm{C}_{5} \mathrm{H}_{9}\right)_{2} \mathrm{Ar}$ ' and $\mathrm{P}\left(c-\mathrm{C}_{6} \mathrm{H}_{11}\right)_{2} \mathrm{Ar}$ ' phosphines prefer a structure of type $\mathbf{C}$, which is also the structure adopted by the related, Buchwald-type, dialkylbiaryl phosphines.

The described analysis of the steric and electronic properties of dialkylterphenyl phosphines leads to the extra conclusion of their accentuated basicity, that is, high overall electron-donor capacity, manifested, for instance, in the elevated metal basicity evinced for $\mathrm{Ni}(0)-\mathrm{PR}_{2} \mathrm{Ar}$ ' units in the two phosphine coordination modes present in $\mathrm{Ni}(\mathrm{CO})_{3}\left(\mathrm{PR}_{2} \mathrm{Ar} r^{\prime}\right)$ and $\mathrm{Ni}(\mathrm{CO})_{2}\left(\mathrm{PR}_{2} \mathrm{Ar}^{\prime}\right)$ complexes.

In perspective, $\mathrm{P}$-binding of $\mathrm{PMe}_{2} \mathrm{Ar}$ ' ligands to transition metal centres is expected on steric grounds, as no F-strain is foreseeable to develop for their most favourable A-type conformation. Nevertheless, when interacting with low-coordinate, highly unsaturated $\mathrm{ML}_{n}$ groups, phosphine polydentate, hemilabile, $\kappa-P, \eta^{n}-C_{\text {arene }}$ coordination could readily be attained, given that, as noted above, conformation $\mathbf{C}$ is easily accessible. Conversely, for the bulkier $\mathrm{P}^{\mathrm{i}} \mathrm{Pr}_{2} \mathrm{Ar}, \mathrm{P}\left(c-\mathrm{C}_{5} \mathrm{H}_{9}\right)_{2} \mathrm{Ar}$, and $\mathrm{P}(c-$ $\left.\mathrm{C}_{6} \mathrm{H}_{11}\right)_{2} \mathrm{Ar}^{\prime}$, monodentate $\mathrm{P}$-coordination can be predicted to originate considerable $\mathrm{F}$-strain, as a consequence of the close proximity of $M L_{n}$ to one of the terphenyl flanking rings, such that this bonding mode is expected only in complexes of $M L_{n}$ fragments of reduced steric hindrance and favourable geometry, e.g. $\mathrm{M}-\mathrm{L}$ and $\mathrm{ML}_{2}$, or planar $\mathrm{ML}_{3}$. Included in the above are, naturally, $\mathrm{M}\left(\mathrm{PR}_{2} \mathrm{Ar}\right)^{+}(\mathrm{M}=\mathrm{Cu}, \mathrm{Ag}, \mathrm{Au})$ and $\mathrm{M}\left(\mathrm{PR}_{2} \mathrm{Ar}\right)_{\mathrm{n}}(\mathrm{M}=\mathrm{Ni}$, $\mathrm{Pd} ; \mathrm{n}=1,2)$ fragments, of well-known high catalytic relevance. The anterior hypothesis finds support in the observation that even the relatively small $\mathrm{Ni}(\mathrm{CO})_{3}$ fragment, with local $C_{3 v}$ symmetry when bonded to $\mathrm{PR}_{2} \mathrm{Ar}$,' cannot form the expected $\mathrm{Ni}(\mathrm{CO})_{3}\left(\mathrm{PR}_{2} \mathrm{Ar} r^{\prime}\right)$ complexes. Instead, harsher reaction conditions are necessary to force the dissociation of another carbon monoxide ligand, to yield complexes $\mathrm{Ni}(\mathrm{CO})_{2}\left(\mathrm{PR}_{2} \mathrm{Ar} \mathrm{r}^{\prime}\right)$. Further work in support of these hypotheses is presently under way, along with related research on the catalytic applications of $\mathrm{G} 10 \mathrm{M}(0)$ and $\mathrm{G} 11 \mathrm{M}(\mathrm{I})$ complexes of dialkylterphenyl phosphines.

\section{Experimental Section}

All preparations and manipulations were carried out under oxygen-free nitrogen, using conventional Schlenk techniques and, when specified, at low temperature. Solvents were rigorously dried and degassed before use. $\mathrm{Mg}\left(\mathrm{Ar} r^{\prime}\right) \mathrm{Br}$ were prepared by following the synthesis reported by Power ${ }^{57}$ for the related $\mathrm{Ar}^{\mathrm{Xyl}_{2}}$ substituted compounds without adding $\mathrm{I}_{2}$ in the last step of the preparation. Ligands $\mathbf{L} 11-\mathbf{L} 16^{28}$ and $\mathrm{Ni}(\operatorname{cod})_{2}{ }^{58}$ were synthesized by following previously reported procedures. $\mathrm{PCl}_{3}$ was distilled prior to use and kept under a nitrogen atmosphere. Other chemicals were commercially available and used as received. Solution NMR spectra were 
recorded on Bruker Avance DPX-300, Avance DRX-400, Avance DRX500 , and $400 \mathrm{Ascend} / \mathrm{R}$ spectrometers. The ${ }^{1} \mathrm{H}$ and ${ }^{13} \mathrm{C}$ resonances of the solvent were used as the internal standard and the chemical shifts are reported relative to TMS. Complete synthetic procedures and characterization data for new compounds are provided in the Supporting Information. A selection of representative syntheses of ligands and $\mathrm{Ni}(0)$ complexes are reported below.

Synthesis of $\mathrm{PMe}_{2} \mathrm{Ar}^{\mathrm{Dtbp}_{2}}$, L1. A freshly prepared solution $\mathrm{Mg}\left(\mathrm{Ar}^{\mathrm{Dtbp}}{ }^{2}\right) \mathrm{Br}$ (3.6 mmol) in THF (ca. $20 \mathrm{~mL}$ ) was added dropwise to a solution of an equimolar amount of $\mathrm{PCl}_{3}$ in THF $(0.30 \mathrm{~mL}, 3.6 \mathrm{mmol})$ at $-80 \stackrel{\circ}{\circ} \mathrm{C}$. The reaction mixture was allowed to reach slowly the room temperature and stirred overnight. All volatiles were removed by evaporation under reduced pressure and the solid residue was extracted three times with pentane ( 3 $\times 10 \mathrm{~mL}$ ). The combined organic fractions were dried under vacuum giving

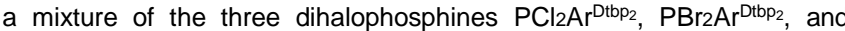
$\mathrm{PCl}(\mathrm{Br}) \mathrm{Ar}^{\mathrm{Dtbp}_{2}}$, as a pale yellow solid, which was redissolved in THF (ca. $20 \mathrm{~mL}$ ). A $3.0 \mathrm{M}$ solution of $\mathrm{Mg}(\mathrm{Me}) \mathrm{Br}$ in $\mathrm{Et} 2 \mathrm{O}(2.6 \mathrm{~mL}, 7.8 \mathrm{mmol})$ was added dropwise at $-80{ }^{\circ} \mathrm{C}$, the mixture was allowed to reach slowly the room temperature, and stirred overnight. The volatiles were removed under reduced pressure and the solid residue was extracted with pentane $(3 \times 10 \mathrm{~mL})$. The combined organic fractions were taken to dryness affording a pale yellow solid which was washed with $\mathrm{MeOH}$ at $0 \stackrel{\circ}{\circ} \mathrm{C}$. Yield: $1.3 \mathrm{~g}(71 \%)$

Synthesis of $\mathbf{P}\left(c-\mathrm{C}_{5} \mathrm{H}_{9}\right)_{2} \mathrm{Ar}^{\mathrm{Xyl}}{ }_{2}$, L6. A $0.50 \mathrm{M}$ solution of $\mathrm{Mg}\left(c-\mathrm{C}_{5} \mathrm{H}_{9}\right) \mathrm{Br}$ in THF $(41 \mathrm{~mL}, 20.6 \mathrm{mmol})$ was added dropwise at $-20{ }^{\circ} \mathrm{C}$ to a stirred solution of $\mathrm{Ar}^{\mathrm{Xyl}_{2} \mathrm{PX}} \mathrm{PX}_{2}(2.0 \mathrm{~g}, 5.2 \mathrm{mmol}$; prepared following the same procedure used for $\mathrm{PX}_{2} \mathrm{Ar}^{\mathrm{Dttp}}{ }_{2}$ in the above synthesis) in THF $(20 \mathrm{~mL})$ in the presence of $\mathrm{CuCl}(0.80 \mathrm{~g}, 7.8 \mathrm{mmol})$. After addition was completed, the dark reaction mixture was allowed to slowly reach room temperature while stirring overnight. The insoluble material was removed by filtration. Volatiles were removed from the resulting solution under reduced pressure and the residue was extracted with pentane $(4 \times 10 \mathrm{~mL})$. The combined organic fractions were again taken to dryness under reduced pressure yielding a pale yellow oil which was treated with $\mathrm{HCl}\left(6 \mathrm{~mL}, 1 \mathrm{M}\right.$ in $\left.\mathrm{Et}_{2} \mathrm{O}\right)$. A colourless solid separated out immediately, which was collected by filtration, washed with pentane $(3 \times 10 \mathrm{~mL})$, and treated with excess aqueous ammonia $(25 \%)$. The aqueous phase was then extracted with $\mathrm{CH}_{2} \mathrm{Cl}_{2}(1 \times 20+2 \times 10 \mathrm{~mL})$ in a separating funnel. The combined organic phases were dried over $\mathrm{MgSO}_{4}$ and the solvent was removed in a rotary evaporator. The resulting pale yellow solid (sticky in some cases) was washed with $\mathrm{MeOH}(2 \times 5 \mathrm{~mL})$ at $0{ }^{\circ} \mathrm{C}$ and, if necessary, recrystallized from $\mathrm{Et}_{2} \mathrm{O} / \mathrm{EtOH}$ (ca. 1:2) at $-32{ }^{\circ} \mathrm{C}$. Yield: $1.4 \mathrm{~g}(58 \%)$.

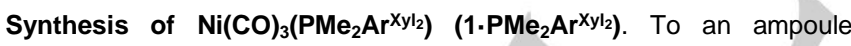
charged with $\mathrm{PMe}_{2} \mathrm{Ar}^{\mathrm{Xyl}_{2}}(0.259 \mathrm{~g}, 0.747 \mathrm{mmol})$ and $\mathrm{Ni}(\operatorname{cod})_{2}(0.206 \mathrm{~g}$, $0.747 \mathrm{mmol})$ ), cooled to $-15^{\circ} \mathrm{C}, \mathrm{THF}(2-5 \mathrm{~mL})$ was added. The vessel was then charged with $\mathrm{CO}$ (1 bar), the cool bath removed, and the solution stirred for ca. $24 \mathrm{~h}$. After removal of volatiles under vacuum, the solid residue was washed with cold $\left(-30^{\circ} \mathrm{C}\right)$ methanol and dried under vacuum affording pure 1.PMe ${ }_{2} \mathbf{A r}^{\mathrm{Xyl}}$, as a colourless powder $(0.234 \mathrm{~g}, 0.477 \mathrm{mmol}$, $64 \%$ yield). Samples suitable for $\mathrm{X}$-ray diffraction were obtained by crystallization from pentane.

$\mathrm{Ni}(\mathrm{CO})_{2}\left(\mathbf{K}^{1}-\mathrm{P}-\eta^{2}-\mathrm{C}, \mathrm{C}-\mathrm{P}^{\mathrm{P} P \mathrm{Pr}_{2}} \mathrm{Ar}^{\mathrm{Dtbp}}{ }_{2}\right)$ (2-L3). To an ampoule charged with $\mathrm{PiPr}_{2} \mathrm{Ar}^{\mathrm{Dtbp}} \mathrm{P}_{2}(0.045 \mathrm{~g}, 0.163 \mathrm{mmol})$ and $\mathrm{Ni}(\operatorname{cod})_{2}(0.073 \mathrm{~g}, 0.128 \mathrm{mmol})$, cooled to $-30^{\circ} \mathrm{C}$, THF $(3 \mathrm{~mL})$ was added. The vessel was then charged with $\mathrm{CO}(1 \mathrm{bar})$ and the cool bath removed. After the yellow colour of $\mathrm{Ni}(\mathrm{cod})_{2}$ disappeared, the mixture was frozen using a liquid $\mathrm{N}_{2}$ bath and all gases were removed under vacuum. Reaction was carried out at $50^{\circ} \mathrm{C}$ for 2 hours, after which removal of volatiles under vacuum resulted in a yellow tacky residue. Crystallization from a $\mathrm{MeOH} / \mathrm{Et}_{2} \mathrm{O}$ mixture at $-30^{\circ} \mathrm{C}$ yielded the sought compound as a yellow crystalline solid $(0.057 \mathrm{~g}, 65 \%$ yield). Although the former method of crystallization resulted in the best yield, traces of unreacted phosphine were found by NMR. Analytically pure samples could be obtained by further recrystallization from pentane at $-30^{\circ} \mathrm{C}$.

\section{Acknowledgements}

We thank MINECO (CTQ2013-42501-P, CTQ2016-75193-P (AEI/FEDER, UE) and CTQ2017-82893-C2-2-R) for financial support. MMG and JJM thank MINECO and the Universidad de Sevilla (V Plan Propio de Investigación), respectively, for research fellowships. We are grateful to María F. Espada and Raquel J. Rama and for assistance with X-ray diffraction studies of phosphines L7 (MFE), L8, L11 and L12 (RJR).

\section{Keywords: phosphines $\cdot$ terphenyl $\bullet$ nickel carbonyls $•$ Tolman} parameters

[1] For some early reviews see for instance: a) Transition Metal Complexes Containing Phosphorus, Arsenic and Antimony Ligands, (Ed.: C. A McAuliffe), Macmillan Press, London, 1973; b) Phosphine, Arsine and Stibine Complexes of the Transition Elements, (Eds.: C. A. McAuliffe, W. Levason), Elsevier Scientific Publishing Company, Amsterdam, 1979; c) L. Malatesta, S. Cenini in Zerovalent Compounds of Metals, Academic Press, London, 1974; d) Homogeneous Catalysis with Metal Phosphine Complexes, (Ed.: L. H. Pignolet), Plenum Press, New York, 1983

[2] a) D. H. Valentine, J. H. Hillhouse, Synthesis 2003, 2437-2460; b) R. H. Crabtree, J. Organomet. Chem. 2005, 690, 5451-5457; c) C. A Fleckenstein, H. Plenio, Chem. Soc. Rev. 2010, 39, 694-711.

[3] M. Bochmann in Organometallics and Catalysis. An Introduction, Oxford University Press, Oxford, 2015; b) R. H. Crabtree in The Organometallic Chemistry of the Transition Metals, John Wiley \& Sons, Inc., Hoboken, 2014; c) J. Hartwig in Organotransition Metal Chemistry: From Bonding to Catalysis, University Science Books, Sausalito, 2010.

[4] A. J. Kendall, D. R.Tyler, Dalton Trans. 2015, 44, 12473-12483.

[5] a) D. W. Old, J. P. Wolfe, S. L. Buchwald, J. Am. Chem. Soc. 1998, 120 9722-9723; b) J. P. Wolfe, R. A. singer, B. H. Yang, S. L. Buchwald, J Am. Chem. Soc. 1999, 121, 9550-9561.

[6] D. S. Surry, S. L. Buchwald, Angew. Chem. Int. Ed. 2008, 47, 6338-6361; b) R. Martin, S. L. Buchwald, Acc. Chem. Res. 2008, 41, 1461-1473; c) D. S. Surry, S. L. Buchwald, Chem. Sci. 2011, 2, 27-50.

[7] X.-F. Wu, X. Fang, L. Wu, R. Jacksell, H. Neumann, M. Beller, Acc. Chem. Res. 2014, 47, 1041-1053.

[8] A. F. Littke, G. C. Fu, Angew. Chem. Int. Ed. 2002, 41, 4176-4211.

[9] a) J. P. Stambuli, S. R. Stauffer, K. H. Shaughnessy, J. F. Hartwig, J. Am. Chem. Soc. 2001, 123, 2377-2678; b) J. F. Hartwig, Acc. Chem. Res. 2008, 41, 1534-1544.

[10] J. Keller, C. Schlierf, C. Nolte, P. Mayer, B. F. Straub, Synthesis 2006 , 354-365.

[11] a) J. Petuškova, M. Patil, S. Holle, C. W. Lehmann, W. Thiel, M. Alcarazo J. Am. Chem. Soc. 2011, 133, 20758-20760; b) J. Petuškova, H. Bruns, M. Alcarazo, Angew. Chem. Int. Ed. 2011, 50, 3799-3802; c) M. Alcarazo, Acc. Chem. Res. 2016, 49, 1797-1805.

[12] a) L. Chen, P. Ren, B. P. Carrow, J. Am. Chem. Soc. 2016, 138, 6392 6395; b) F. Buß, P. Mehlmann, C. Mück-Lichtenfeld, K. Bergander, F. Dielmann, J. Am. Chem. Soc. 2016, 138, 1840-1843; c) J. R. McAtee, G. P. A. Yap, D. A. Watson, J. Am. Chem. Soc. 2014, 136, 10166-10172; d) F. Proutiere, E. Lyngvi, M. Aufiero, I. A. Sanhueza, F. Schoenebeck, Organometallics 2014, 33, 6879-6884.

[13] a) A. Kondoh, H. Yorimitsu, K. Oshima, J. Am. Chem. Soc. 2007, 129 6996-6997; b) C. A. Lugo, C. E. Moore, A. L. Rheingold, V. Lavallo, Inorg Chem. 2015, 54, 2094-2096; c) S. Doherty, J. C. Knight, N. A. B. Ward D. M. Bittner, C. Willis, W. McFarlane, W. Clegg, R. W. Harrington, Organometallics 2013, 32, 1773-1778; d) K. T. Horak, D. G. Vandervelde, T. Agapie, Organometallics 2015, 34, 4753-4765.

[14] a) Y.-N. Ma, S.-X. Li, S.-D. Yang, Acc. Chem. Res. 2017, 50, 1480-1492 b) R.-B. Hu, H. Zhang, X.-Y. Zhang, S.-D. Yang, Chem. Commun. 2014 50, 2193-2195; c) H. Zhang, R.-B. Hu, X.-Y. Zhang, S.-X. Li, S.-D. Yang, Chem. Commun. 2014, 50, 4686-4689.

[15] X. Qiu, M. Wang, Y. Zhao, Z. Shi, Angew. Chem. Int. Ed. 2017, 56, 72337237. 
[16] a) K. Wu, A. G. Doyle, Nat. Chem. 2017, 9, 779-784; b) Z. L. Niemeyer, A. Milo, D. P. Hickey, M. S. Sigman, Nat. Chem. 2016, 8, 610-617; c) A. H. Christian, Z. L. Niemeyer, M. S. Sigman, F. D. Toste, ACS Catal. 2017 7, 3973-3978

[17] a) D. L. Liptrot, D. P. Power, Nat. Rev. Chem. 2017, 1, 0004; b) J. P. Wagner, P. R. Schreiner, Angew. Chem. Int. Ed. 2015, 54, 12274-12296 c) J.-D. Guo, D. J. Liptrot, S. Nagase, P. P. Power, Chem. Sci. 2015, 6 , 6235-6244.

[18] C. A. Tolman, Chem. Rev. 1977, 77, 313-348.

[19] a) A. Poater, B. Cosenza, A. Correa, S. Giudice, F. Ragone, V. Scarano, L. Carvallo, Eur. J. Inorg. Chem. 2009, 1759-1766; b) H. Clavier, S. P. Nolan, Chem. Commun. 2010, 46, 841-861.

[20] a) T. Nguyen, A. D. Sutton, M. Brynda, J. C. Fettinger, G. J. Long, P. P. Power, Science 2005, 310, 844; b) R. Wolf, M. Brynda, C. Ni, G. J. Long, P. P. Power, J. Am. Chem. Soc., 2007, 129, 6076; C) C. Ni, B. D. Ellis, J. C. Fettinger, G. J. Long, P. P. Power, Chem. Commun. 2008, 0, 1014; d) K. V. Bukhryakov, R. R. Schrock, A. H. Hoveyda, P Müller, J. Becker, Org. Lett. 2017 19, 2607; (e) M. Carrasco, M. Faust, R. Peloso, A. Rodríguez, J. LópezSerrano, E. Álvarez, C. Maya, P. P. Power, E. Carmona, Chem. Commun. 2015, 48, 3954; f) M. Carrasco, I. Mendoza, M. Faust, J. López-Serrano, R. Peloso, A. Rodríguez, E. Álvarez, C. Maya, P. P. Power, E. Carmona, J. Am. Chem. Soc. 2014, 136, 9173; g) M. Carrasco, I. Mendoza, E. Álvarez, A. Grirrane, C. Maya, R. Peloso, A. Rodríguez, A. Falceto, S. Álvarez, E. Carmona, Chem. Eur. J. 2015, 21, 410

[21] a) L. C. H. Gerber, R. R. Schrock, P. Müller, M. K. Takase, J. Am. Chem. Soc., 2011, 133, 18142; b) B. R. Barnett, M. L. Neville, C. E. M. A. L. Rheingold, J. S. Figueroa, Angew. Chem. Int. Ed. 2017, 56, 7195; c) H. F. T. Klare, M. Oestreich, J.-i. Ito, H. Nishiyama, Y. Ohki, K. Tatsumi, J. Am. Chem. Soc. 2011, 133, 3312; d) C. Jones, M. Waugh, J. Organomet. Chem. 2007, 692, 5086; e) A. Hinz, A. Schulz, A. Villinger, Inorg. Chem. 2016, 55, 3692; f) M. Nutz B. Borthakur, R. D. Dewhurst, A Deißenberger, T. Dellermann, M. Schäfe, I. Krummenacher, A. K Phukan, H. Braunschweig, Angew.Chem. Int .Ed. 2017, 56, 7975; g) H. Braunschweig, R. D. Dewhurst, F. Hupp, M. Nutz, K. Radacki, C. W. Tate A. Vargas, Q Ye, Nature 2015, 522, 327; h) P. Ghana, M. I. Arz, U. Das, G. Schnakenburg, A. C. Filippou, Angew. Chem. Int. Ed. 2015, 54, 9980; i) C. M. E. Graham, T. E. Pritchard, P. D. Boyle, J. Valjus, H. M. Tuononen, P. J. Ragogna, Angew. Chem. Int. Ed. 2017, 56, 6236

[22] a) M. Carrasco, R. Peloso, A. Rodríguez, E. Álvarez, C. Maya, E. Carmona, Chem. Eur. J. 2010, 16, 9754; b) M. Carrasco, R. Peloso, I. Resa, A. Rodríguez, L. Sánchez, E. Álvarez, C. Maya, R. Andreu, J. J. Calvente, A. Galindo, E. Carmona Inorg. Chem. 2011, 50, 6361

[23] a) R. C. Smith, R. A. Woloszynek, W. Chen, T. Ren, J. D. Protasiewicz, Tetrahedron Lett. 2004, 45, 8327-8330; b) D. V. Partyka, M. P. Washington, J. B. Updegraff III, X. Chen, C. D. Incarvito, A. L. Rheingold, J. D. Protasiewicz, J. Organomet. Chem. 2009, 694, 1441-1446.

[24] a) B. Buster, A. A. Diaz, T. Graham, R. Khan, M. A. Khan, D. R. Powell, R. J. Wehmschulte, Inorg. Chim. Acta 2009, 362, 3465; b) A. A. Díaz, J. D. Young, M. A. Khan, R. J. Wehmschulte, Inorg. Chem. 2006, 45, 55685575 .

[25] a) S. Sasaki, R. Chowdhury, M. Yoshifuji, Tetrahedron Lett. 2004, 45 9193-9196; b) S. Sasaki, M. Izawa, M. Yoshifuji, Phosphorus, Sulfur Silicon Relat. Elem. 2014, 189, 1207-1215; c) T. Fujihara, K. Semba, J. Terao, Y. Tsuji, Angew. Chem. Int. Ed. 2010, 49, 1472-1476.

[26] a) J. Campos, L. Ortega-Moreno, S. Conejero, R. Peloso, J. LópezSerrano, C. Maya, E. Carmona, Chem. Eur. J. 2015, 21, 8883-8896; b) M.F. Espada, J. Campos, J. López-Serrano, M.L. Poveda, E. Carmona, Angew. Chem. Int. Ed. 2015, 54, 15379-15384.

[27] J. Moreno, M. F. Espada, E. Krüger, J. López-Serrano, J. Campos, E. Carmona, Eur. J. Inorg. Chem. 2018, 2309-2321.

[28] L. Ortega-Moreno, M. Fernández-Espada, J. J. Moreno, C. NavarroGilabert, J. Campos, S. Conejero, J. López-Serrano, C. Maya, R. Peloso, E. Carmona, Polyhedron 2016, 116, 170-181.

[29] For the first dimethylbiaryl phosphine, Methyl-JohnPhos see: a) A. J. Kendall, L. N. Zakharov, D. R. Tyler, Inorg. Chem. 2016, 55, 3079; b) A. J. Kendall, C. A. Salazar, P. E. Martino, D. R. Tyler, Organometallics 2014, 33, 6171-6178.
[30] a) M. Grellier, S. Sabo-Etienne, Chem. Commun. 2012, 48, 34-42; b) P. D. Bolton, M. Grellier, N. Vautravers, L. Vendier, S. Sabo-Etienne, Organometallics 2008, 27, 5088-5093;

[31] M. Grellier, L. Vendier, S. Sabo-Etienne, Angew. Chem. Int. Ed. 2007, 46, 2613-2615.

[32] a) T. M. Douglas, S. K. Brayshaw, R. Dallanegra, G. Kociok-Köhn, S. A. Macgregor, G. L. Moxham, A. S. Weller, T. Wondimagegn, H. P. Vadivelu, Chem. Eur. J. 2008, 18, 1004-1022; b) R. Dallanegra, A. B. Chaplin, A. S. Weller, Angew. Chem. Int. Ed. 2009, 48, 6875-6878.

[33] a) R. Dallanegra, A. B. Chaplin, J. Tsim, A. S. Weller, Chem. Commun 2010, 46, 3092-3094; b) R. Dallanegra, A. B. Chaplin, A. S. Weller Organometallics 2012, 31, 2720-2728.

[34] a) H. C. Brown, J. Chem. Soc. 1956, 1248-1268; b) J. Huheey, E. A. Keiter, R. L. Keiter in Inorganic Chemistry: Principles of Structure and Reactivity, $4^{\text {th }}$ Ed, HarperCollins, New York, 1993, pp 341-342.

[35] a) C. A. Tolman, J. Am. Chem. Soc. 1970, 92, 2953-2956; b) C. A. Tolman, J. Am. Chem. Soc. 1970, 92, 2956-2965.

[36] The Cambridge Structural Database. C. R. Groom, I. J. Bruno, M. P. Lightfoot and S. C. Ward, Acta Cryst. 2016, B72, 171-179. DOI: 10.1107/S2052520616003954

[37] a) H. Tomari, J. M. Fox, S. L. Buchwald, J. Org. Chem. 2000, 65, 5334 5341 ; b) S. Kaye, J. M. Fox, F. A. Hicks, S. L. Buchwald, Adv. Synth Catal. 2001, 343, 789-794; c) N. Hoshiya, S. L. Buchwald, Adv. Synth Catal. 2012, 354, 2031-2037.

[38] S. O. Grim, W. McFarlane, E. F. Davidoff, J. Org. Chem. 1967, 32, 781.

[39] O. Kühl in Phosphorus-31 NMR Spectroscopy: A Concise Introduction for the Synthetic Organic and Organometallic Chemist, Springer-Verlag, Berlin Heidelberg. 2008.

[40] a) T. E. Barder, S. L. Buchwald, J. Am. Chem. Soc. 2007, 129, 5096 5101; b) L. Bonnafoux, F. R. Leroux, F. Colobert, Beilstein J. Org. Chem. 2011, 7, 1278-1287; c) R. Pratap, D. Parrish, P. Gunda, D. Venkataraman, M K. Lakshman, J. Am. Chem. Soc. 2009, 121, 1224012249.

[41] L. Pauling in The Nature of the Chemical Bond, Cornell University Press, New York, 1960

[42] a) B. J. Dunne, R. B. Morris, A. G. Orpen, J. Chem. Soc., Dalton Trans. 1991, 653-661; b) T. L. Brown, K. J. Lee, Coord. Chem. Rev. 1993, 128 89-116.

[43] B. Cordero, V. Gómez, A. E. Platero-Prats, M. Revés, J. Echeverría, E. Cremades, F. Barragán, S. Alvarez, Dalton. Trans. 2008, 2832.

[44] a) D. Schaarschmidt, J. Kühnert, S. Tripke, H. G. Alt, C. Görl, T. Rüffer P. Ecorchard, B. Walfort, H. Lang, J. Organomet. Chem. 2010, 695, 1541-1549; b) A. V. Zakharov, Y. V. Vishnevskiy, N. Allefeld, J. Barder, B. Kurscheid, S. Steinhauer, B. Hoge, B. Newmann, H.-G. Stammler, R. J. F. Berger, N. W. Mitzel, Eur. J. Inorg. Chem. 2013, 3392-3404; c) J. Pickardt, L. Rösch, H. Schumann, Z. Anorg. Allg. Chem. 1976, 426, 6676.

[45] A. Velian, S. Lin, A. J. M. Miller, M. W. Day, T. Agapie, J. Am. Chem. Soc 2010, 132, 6296-6297.

[46] O. Diebolt, G. C. Fortman, H. Clavier, A. M. Z. Slawin, E. C. EscuderoAdán, J. Benet-Buchholz, S. P. Nolan, Organometallics 2011, 30, 16681676

[47] For early work in this field see: P. W. Jolly, G. Wilke in The Organic Chemistry of Nickel, Vol. I, Academic Press, New York, 1974

[48] a) W. Reppe, W. J. Sweckendiek, Justus Liebigs Ann. Chem. 1948, 560 104-116; b) L. S. Meriwether, M. L. Fiene, J. Am. Chem. Soc. 1959, 81 4200-4208.

[49] a) A. R. Chinaese, X. Li, M. C. Janzen, J. W. Faller, R. H. Crabtree, Organometallics 2003, 22, 1663-1667; b) R. A. Kelly III, H. Clavier, S. Giudice, N. M. Scott, E. D. Stevens, J. Bordner, I. Samardjev, C. D. Hoff, L. Carvallo, S. P. Nolan, Organometallics 2008, 27, 202-210.

[50] See for example Chapter V of reference 47.

[51] a) W. Petz, F. Weller, J. Uddin, G. Frenking, Organometallics 1999, 18, 619; b) R. Dorta, E. D. Stevens, N. M. Scott, C. Constabile, L. Carvallo, C. D. Hoff, S. P. Nolan, J. Am. Chem. Soc. 2005, 127, 2485-2495; c) U. S. Paul, C. Sieck, M. Haehnel, K. Hammond, T. B. Marder, U. Radius, Chem. Eur. J. 2016, 22, 11005-11014; d) U. S. d. Paul, U. Radius, Organometallics 2017, 36, 1398-1407. 
[52] S. E. Kegley, A. R. Pinhas in Problems and Solutions in Organometallic Chemistry, Chapter 4, University Science Books, Mill Valley, CA, 1986.

[53] F. A. Cotton, G. Wilkinson in Advanced Inorganic Chemistry, $5^{\text {th }}$ Edition, Wiley, New York, 1988, p. 60

[54] A. Falceto, E. Carmona, S. Alvarez, Organometallics 2014, 33, 66606668.

[55] a) B. Bogdanović, M. Kröner, G. Wilke, Liebigs Ann. Chem. Bd. 1966, 699, 1-23; b) C. D. Cook, C. H. Koo, S. C. Nyburg, M. T. Shiomi, Chem. Commun. 1967, 426b-427.
[56] G. Stucky, S. D’Agostino, G. McPherson, J. Am. Chem. Soc. 1966, 88, 4828

[57] a) B. Schiemenz, P. P. Power, Organometallics 1996, 15, 958; b) R. S Simons, S. T. Haubrich, B. V. Mork, M. Niemeyer, P. P. Power, Main Group Chem. 1998, 2, 275.

[58] J. W. Wielandt, D. Ruckerbauer, Inorg. Synth. 2010, 35, 120 
Entry for the Table of Contents (Please choose one layout)

Layout 1:

\section{FULL PAPER}

$\mathbf{R}$ groups control the coordination mode of terphenyl phosphines in $\mathrm{Ni}(\mathrm{CO})_{\mathbf{n}}\left(\mathrm{PR}_{2} \mathrm{Ar} \mathbf{r}^{\prime}\right)$ complexes. Steric and electronic parameters of a series of dialkylterphenyl phosphines, $\mathrm{PR}_{2} \mathrm{Ar}^{\prime}$ have been determined computationally and experimentally. $\mathrm{PR}_{2} \mathrm{Ar}^{\prime}$ units shows two different coordination modes in $\mathrm{Ni}(\mathrm{CO})_{3}\left(\mathrm{PR}_{2} \mathrm{Ar} r^{\prime}\right)$ and $\mathrm{Ni}(\mathrm{CO})_{2}\left(\mathrm{PR}_{2} \mathrm{Ar}^{\prime}\right)$ complexes that depend on the size of the $\mathrm{R}$ groups.
Mario Marín, ${ }^{[b]}$ Juan J. Moreno, ${ }^{[a]}$ Carlos Navarro-Gilabert, ${ }^{[a]}$ Eleuterio Álvarez, ${ }^{[a]}$ Celia Maya, ${ }^{[a]}$ Riccardo Peloso, ${ }^{[a]} \mathrm{M}$. Carmen Nicasio, ${ }^{*[b]}$ Ernesto Carmona ${ }^{*[a]}$

Page No. - Page No.

Synthesis, Structure and Nickel Carbonyl Complexes of Dialkylterphenyl Phosphines 